\title{
The emerging role of epigenetics in human autoimmune disorders
}

\author{
Roberta Mazzone ${ }^{1,2}$, Clemens Zwergel ${ }^{1}$, Marco Artico ${ }^{3}$, Samanta Taurone ${ }^{4}$, Massimo Ralli ${ }^{3}$, Antonio Greco ${ }^{3}$ and \\ Antonello Mai ${ }^{1,5^{*}}$ (i)
}

\begin{abstract}
Epigenetic pathways play a pivotal role in the development and function of the immune system. Over the last decade, a growing body of studies has been published out seeking to explain a correlation between epigenetic modifications and the development of autoimmune disorders. Epigenetic changes, such as DNA methylation, histone modifications, and noncoding RNAs, are involved in the pathogenesis of autoimmune diseases mainly by regulating gene expression. This paper reviews the importance of epigenetic alterations during the development of the most prevalent human autoimmune diseases, such as systemic lupus erythematosus (SLE), rheumatoid arthritis (RA), systemic sclerosis (SSc), Sjogren's syndrome (SS), autoimmune thyroid diseases (AITD), and type 1 diabetes (T1D), aiming to provide new insights in the pathogenesis of autoimmune diseases and the possibility to develop novel therapeutic approaches targeting the epigenome.
\end{abstract}

Keywords: Epigenetics, Gene expression, Autoimmune diseases, Epigenetic pathways

\section{Background}

Epigenetic mechanisms, known for their ability to regulate gene transcription and genomic stability, are key players for maintaining normal cell growth, development, and differentiation [1]. The term "epigenetics" can be outlined as the meiotically/mitotically heritable alterations in gene expression, related to environmental factors, without changes to the sequence of bases in the DNA [1]. Since genome-wide profiling in some cases does not give a sufficient answer to explain the complex biological processes in autoimmune disorders, epigenetic modifications are retained additional regulators in immune responses (Fig. 1). Epigenetic dysregulation directly influences the development of autoimmunity by regulating immune cell functions [2]. The recognition of the complexity of the interaction between epigenetic events and the alteration of the immune system in autoimmune disorders is a prominent challenge for the discovery of novel potential therapeutic strategies. Epigenetic mechanisms, such as DNA methylation,

\footnotetext{
*Correspondence: antonello.mai@uniroma1.it

${ }^{1}$ Department of Chemistry and Technologies of Drugs, Sapienza University of Rome, P.le A. Moro 5, 00185 Rome, Italy

${ }^{5}$ Pasteur Institute - Cenci Bolognetti Foundation, Sapienza Università di

Roma, P.le Aldo Moro 5, 00185 Rome, Italy

Full list of author information is available at the end of the article
}

chromatin remodeling, and noncoding RNAs, have been identified as crucial regulators in cellular immunity, owing to their mechanisms in modulating gene expression and transcription in targeted cells and tissues [3]. Extensive evidences indicate that autoimmune diseases are mainly an interplay of genetic and non-genetic factors, although the role of the latter ones often remains unclear. Over the last decade, the influence of epigenetic modifications on innate and adaptive immunity has been intensively investigated, especially in autoimmune disorders.

\section{Epigenetic mechanisms DNA methylation}

DNA methylation is one of the most studied epigenetic marks and typically occurs at the pyrimidine $\mathrm{C} 5$ position of cytosine residues by transferring a methyl group from $S$-adenosyl-L-methionine (SAM) through the catalytic action of DNA methyltransferases (DNMTs) [4-6]. DNA methylation influences a large variety of biological processes such as transcriptional repression, reversible promoter silencing, and chromosomal instability [7, 8]. The various functions and diverse subtypes of DNMTs have been summarized well in various reviews [9-11]. 


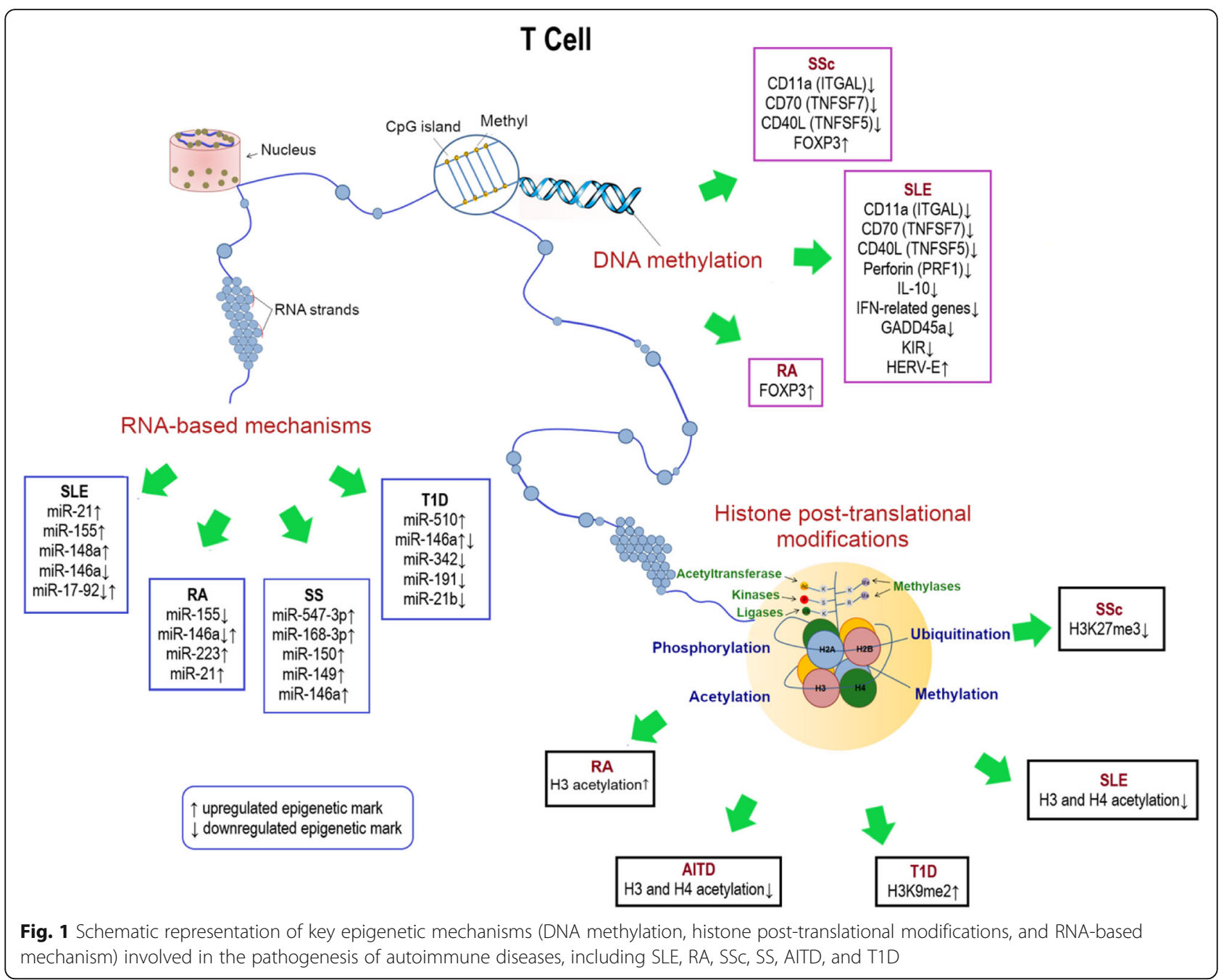

One of the crucial functions of DNA methylation is the maintenance of the $\mathrm{T}$ cell regulation. Recent findings underlined the critical role of DNA methylation in numerous autoimmune diseases by altering gene expression profiles [12-15]. Several factors such as environmental influences, genetic variants, drugs, and miRNAs influencing the DNA methylation status have been linked to autoimmune disorders.

\section{Histone modifications}

Histone-modifying enzymes have an essential role in modulating chromatin compaction state, nucleosomal processes, and DNA repair [16-18]. Some HDAC inhibitors (HDACi) have been widely studied as a means to increase the transcription of various genes, including those involved in autoimmunity [19-21]. Moreover, HDACi have been described to influence immune and inflammatory processes, mainly involving $\mathrm{T}$ cells $[22,23]$. Acetyl and methyl marks inserted on histones could also interact with the corresponding "reader" proteins to add complexity to this scenario. Some evidence suggested that posttranslational modifications are implicated in the development and regulation of different cell lines and in the modulation of immune tolerance and autoimmune disorders $[24,25]$.

\section{Noncoding RNAs}

Long noncoding RNAs (lncRNAs) are a huge and diverse class of transcribed RNA molecules with a length of more than 200 nucleotides. Usually, they are capped, polyadenylated, and spliced without having any coding function for proteins [26]. LncRNAs have been described as key players of gene regulation in various human pathologies due to their implication in numerous cellular and biological events regulating heterochromatin formation, histone modifications, DNA methylation targeting, and gene silencing [27, 28]. Furthermore, IncRNA can activate regulatory complexes regulating the development and differentiation of various immune cell types via an active protein expression control. MiRNAs are 
responsible for the regulation of about $60 \%$ of all mRNAs and are implicated in numerous disorders, such as cancers, inflammatory processes, and metabolic diseases $[29,30]$. Due to their essential role in the hematopoietic development, as well as cell activation and differentiation, abnormal expression of miRNAs might lead to the onset of autoimmune diseases [31, 32].

\section{Systemic and organ-specific autoimmune diseases}

Autoimmune diseases are characterized by an immune response to antigenic components of the host itself (autoantigens). Two main types of autoimmune diseases can be distinguished: on the one hand, the systemic ones and on the other, the organ-specific ones. In systemic diseases, the immune system attacks in a generalized manner its own antigens in several organs, while in organ-specific diseases the immune response is directed towards a single organ. Examples of systemic and organ-specific autoimmune diseases with known autoantigen targets are illustrated in Table 1.

\section{Systemic autoimmune rheumatic diseases (SARDs)}

Systemic autoimmune rheumatic diseases (SARDs) belong to a group of rare chronic inflammatory conditions including rheumatoid arthritis (RA), systemic lupus erythematosus (SLE), systemic sclerosis (SSc), and Sjogren's syndrome (SS). Autoimmunity is defined by the breakdown of self-tolerance that produces a state of abnormal humoral and cell-mediated responses against self-components. Collectively, SARDs affect up to $5 \%$ of the world population and, in particular, people of work-force age [33, 34]. Until now, no effective treatments have been identified for SARDs, even though the use of glucocorticoids has been considered as a first-line therapy. Nowadays, however, antimalarial and immunosuppressive drugs are most commonly used due to their limited long-term side effects. Such autoimmune disorders are often associated with an autoimmune dysregulation which determines morbidity and, in most cases, premature mortality $[35,36]$. In particular, most of these conditions happen when the immune system produces autoantibodies (ANA) directed against intracellular antigens. So, ANA are considered as convincing serological hallmarks of SARDs, which are routinely detected via an indirect immunofluorescence (IF) assay [37]. Although many progresses have been performed in the last 15 years, there is an unmet need to find an innovative and successful therapy to fight SARDs, especially RA, the most prevalent autoimmune disease. Understanding the molecular mechanisms of SARDs appears to be extremely important to achieve beneficial outcomes in these chronic conditions. However, similar biologic pathways that underlie SARDs in RA, SLE, and SSc may suggest novel mechanistic similarities. Indeed, these three chronic diseases have in common demographic distribution (the most affected individuals are women), some signs and symptoms (arthritis, lung and vascular disease), serological elements (ANA and anti-Ro52/ TRIM21 antibodies), immunological components (type I interferon signature and complex abnormalities in CD4C T lymphocyte function, in particular Th17 and Treg cell subsets), and genetic similarities (e.g., MHC class II alleles, IRF5, STAT4, PTPN22 loci) [38-44]. More and more studies demonstrated that epigenetically altered immune components, such as $\mathrm{CD} 4^{+} \mathrm{T}$ cells and costimulatory molecules, are key drivers of SARDs, thereby compromising cellular immune system function and regulation [45-48]. Characterization of epigenetic modifications that occur across these autoimmune diseases may yield valuable insights into their pathogenesis and treatment. Thus, in an attempt to determine the most important epigenetic changes in SARDs, researchers investigated the role of epigenetic processes in regulating autoimmunity. For many years, epigenetic implications for the most important related forms of autoimmunity including RA, SLE, SSc, and SS have been studied in order to find a tight association between epigenetics and systemic autoimmune, providing novel regulatory mechanisms for SARDs (Table 2).

\section{Systemic lupus erythematosus (SLE)}

SLE is the most studied autoimmune disease correlated with epigenetic modification. It especially occurs in women and is mainly caused by dysregulation of $\mathrm{T}$ lymphocytes, making the disorder complicated and hard to handle. SLE is a chronic autoimmune dysfunction characterized by the development of autoantibodies against nuclear antigens affecting any organ system and tissue, such as kidney and blood vessels. In a recent study, neutrophils and granulocytes from patients with SLE have been described as totally hypomethylated, especially at the gene locus of the interferons $M X 1$ and IFI44L [49]. Discrepancies in monozygotic twins propone environmental factors as crucial drivers for the development of SLE. Epigenetic alterations such as DNA methylation and histone modifications have been found to be able to regulate gene expression in mature $\mathrm{T}$ cells. Numerous genes such as CD11a (ITGAL), perforin (PRF1), CD70 (TNFSF7), and CD40LG (TNFSF5) in T lymphocytes of SLE patients were found to be hypomethylated [50]. Early studies in SLE CD4 ${ }^{+} \mathrm{T}$ cells demonstrated a conversion to autoreactivity and an induced lupus-like syndrome after treatment with DNMT inhibitors [51-53]. The auto-reactivity has been shown only in cloned and polyclonal human and murine $\mathrm{CD}^{+}$cells, but not in $\mathrm{CD}^{+}$cells, the reason is still undetermined $[53,54]$. However, there is strong evidence that auto-reactivity development is concomitant with an increased expression of the 


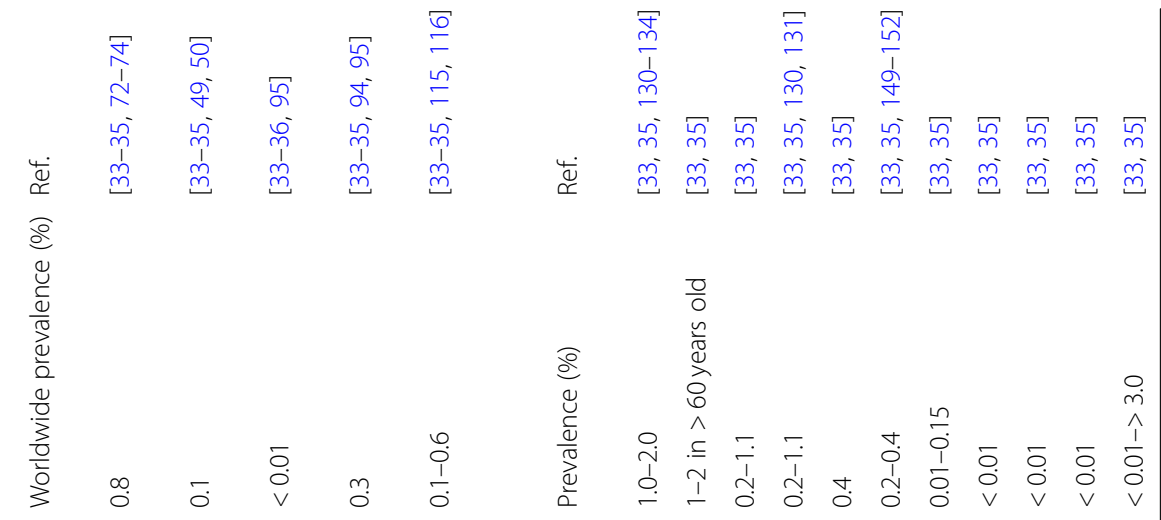

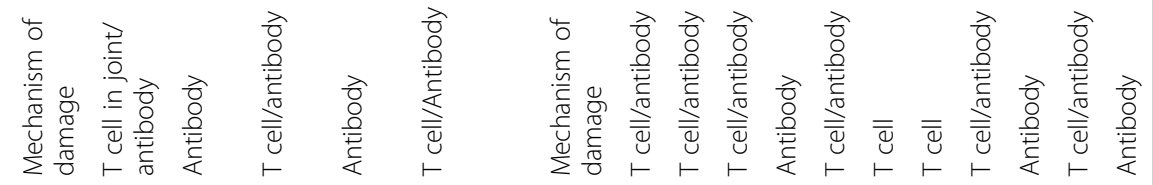

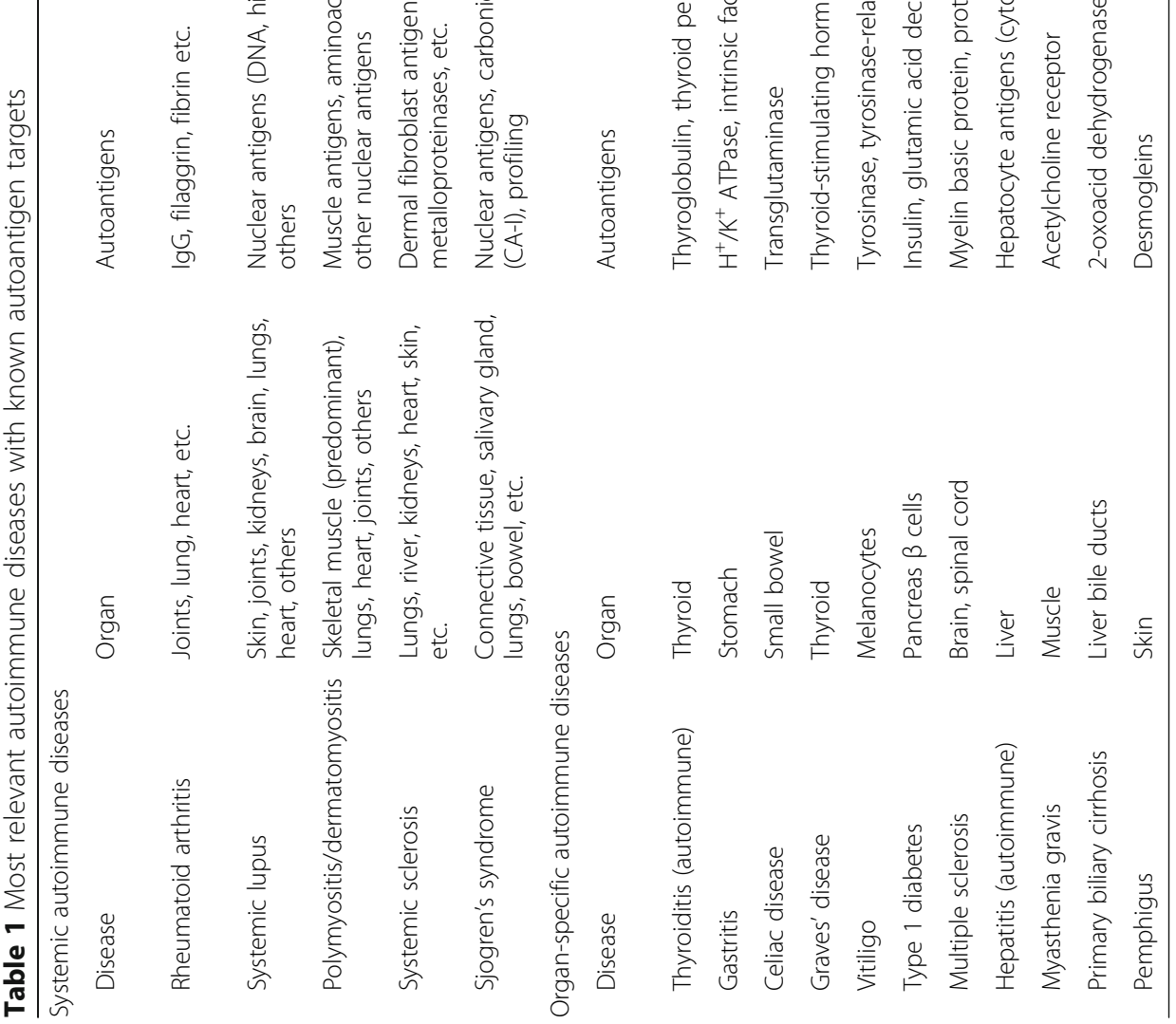


Table 2 Epigenetic changes in systemic lupus erythematosus (SLE), rheumatoid arthritis (RA), systemic sclerosis (SSc) and Sjogren's syndrome (SS)

\begin{tabular}{|c|c|c|c|}
\hline Autoimmune disease & DNA methylation & Histone modification & miRNA \\
\hline SLE & $\begin{array}{l}\downarrow \text { CD70, } \downarrow \text { CD11a, } \\
\downarrow \text { CD40L, } \downarrow \text { perforin } \\
\downarrow T \text { cell } \\
\downarrow \text { IFN signature }[50-63]\end{array}$ & $\begin{array}{l}\uparrow \mathrm{H} 3, \mathrm{H} 4 \text { methylation } \\
\uparrow \mathrm{H} 3, \mathrm{H} 4 \text { acetylation [64-67] }\end{array}$ & $\uparrow \operatorname{miR}-21, \uparrow$ miR-148a [68-71] \\
\hline RA & $\begin{array}{l}\downarrow T \text { cell } \\
\uparrow \text { Synoviocytes }[79,80]\end{array}$ & $\uparrow \mathrm{H3}$ acetylation [82-88] & $\begin{array}{l}\uparrow \text { miR-146a, strong link between many } \\
\text { microRNAs and DNA methylation [90-93] }\end{array}$ \\
\hline SSC & $\begin{array}{l}\downarrow T \text { cell } \\
\downarrow \text { Fibroblasts } \\
\uparrow \text { Wnt pathway genes }[96-98,102,103]\end{array}$ & $\begin{array}{l}\text { Fibroblasts: } \downarrow H 3, \mathrm{H} 4 \text { acetylation } \\
{[104,107,108]}\end{array}$ & $\uparrow$ miR-29a, $\uparrow$ miR-196a [109-114] \\
\hline SS & $\begin{array}{l}\downarrow \text { Type-I IFN pathway genes } \\
\downarrow \text { T cells }[115-121]\end{array}$ & No large-scale analysis & $\uparrow \operatorname{miR}-146 a[122]$ \\
\hline
\end{tabular}

adhesion molecules LFA-1 (CD11a/CD18), due to elevated levels of CD11a (ITGAL) transcripts. ITGAL is an integrin responsible for costimulation and cellular adhesion. The upstream promoter of ITGAL can be found to be demethylated in SLE patients' $\mathrm{CD} 4^{+}$cells and depending on the disease activity, and progression CD11a can be found more or less overexpressed [55]. The methylation status of other specific genes has been linked with SLE pathogenesis and development. CD40L, a type II transmembrane protein encoded on the $\mathrm{X}$ chromosome by $C D 4 O L G$ and functioning as a costimulatory molecule, has been found to be overexpressed in human SLE patients. It still remains elusive why SLE predominantly affects women. CD4OLG methylation patterns have been associated with female susceptibility to this disease [56]. Following treatment with DNMT inhibitors (azacytidine, procainamide) or ERK pathway inhibitors (hydralazine, PD98059), demethylated CD40LG led to induced T cell autoreactivity in vitro [56]. Overexpressed E4BP4 (NFIL3), an important human transcription factor, led to the downregulation of the autoimmune responses in SLE patients through inhibiting CD40L expression [57]. Another interesting costimulatory molecule is CD70, encoded by TNFSF7, a ligand of CD27. Disruption of CD70-CD27 interaction via blocking antibody allows attenuating lectin-stimulated B cells' IgG production in vitro [58]. Overexpression in a mouse model can be caused both by traditional demethylating agents and medications associated with drug-induced lupus, including hydralazine and procainamide [59]. Overexpression of CD11a and CD70 in $\mathrm{CD}^{+}$cells after histone methyltransferase SUV39H1 recruitment resulted in decreased regulatory factor X1 (RFX1) levels are important for the determination of $\mathrm{CD}^{+}{ }^{+} \mathrm{T}$ cell auto-reactivity $[60,61]$. Sunahori et al. could demonstrate that inhibiting the catalytic subunit of protein phosphatase 2A (PP2Ac) increased MEK/ERK phosphorylation levels and elevated DNA methylation levels as well as diminished CD70 gene expression [62]. Perforin (PRF1), a key regulator gene in cytotoxic CD8 ${ }^{+}$ and NK cells, produces a cytolytic protein allowing the disruption and lysis of target cellular membranes [63]. PRF1 overexpression in both $\mathrm{CD}^{+}$and $\mathrm{CD}^{+}$cells, mediated by the gene promoting methylation state, has been linked to SLE. Overexpression of IL10 in T cells from SLE patients is modulated by abnormal STAT3 activation through the histone acetyltransferase p300 leading to an increase of specific autoantibody production and tissue damage [64]. Another important interleukin, IL13, has been considered to play a pivotal role in the development of both human and murine lupus via Th2 cell differentiation [65]. Histone modification pattern in lupus has been less investigated than DNA methylation. A heavily methylated HDAC6 promoter resulted in lower HDAC6 mRNA expression in SLE patients if compared to healthy controls [66]. MRLlpr lupus-prone mouse splenocytes showed increased methylation as well as decreased acetylation of histones $\mathrm{H} 3$ and $\mathrm{H} 4$ compared to control mice; treatment with HDAC inhibitors (HDACi) normalizes aberrant gene expression thus reducing disease activity. However, when lupus $\mathrm{T}$ cells are treated by $\mathrm{HDACi}$, including trichostatin A (TSA) and suberoylanilide hydroxamic acid (SAHA), alterations of acetylation levels of acid nuclear transport proteins, transcription factors, and cytoskeleton proteins have been reported [67]. Thus, no valid evidence has been found yet to connect the histone modifications with SLE activity. Several recent studies investigated the role of IncRNAs in lupus pathogenesis. MiR-21, miR-148a, and miR126 are three microRNAs regulated by methylation that are matched with a decreased expression of DNMTs in $\mathrm{CD}^{+} \mathrm{T}$ cells of SLE [68]. MiR-148a elicited the expression of CD70 and CD11a, similar to lupus patients [69]. Further, overexpressed miR-155 has been found in Treg cell of MRLlpr mice. Its $\mathrm{T}$ cell distribution regulating activity has been proven in miR-155 deficient mice which display reduced serum levels of IL4 and IL17A, two specific cytokines secreted by Th2 and Th17 cells, respectively [70]. Another study describes increased 
serum levels of RANTES in SLE patients harboring, at the same time, lowered MiR-125a expression [71].

\section{Rheumatoid arthritis (RA)}

RA is a chronic and debilitating inflammatory sickness causing destructive arthritis with diffuse damages to joints. Epigenetic mechanisms involved in RA include altered methylation stati in $\mathrm{T}$ and $\mathrm{B}$ cells as well as in synovial fibroblasts [72-74]. Early methylation studies revealed that patients' $\mathrm{T}$ cells showed a remarkable phenotype, similar to SLE, characterized by global hypomethylation $[75,76]$. In particular, methotrexate (MTX), used to treat RA, led to the accumulation of protective Treg cells by inducing FOXP3 expression through the promoter demethylation. However, other secondary effects of MTX, which is namely a folate antagonist, on the RA evolution cannot yet be ruled out. Further studies have shown that MTX can reverse the hypomethylated status in peripheral blood mononuclear cells (PBMC) [77, 78]. In 2012, Nakano and colleagues reported the first epigenome-wide study comparing RA and osteoarthritis (OA) FLS cell lines: out of 1859 differently methylated loci, around $60 \%$ were identified as hypermethylated [79]. Thanks to a second recent genome-wide study by de La Rica et al., novel target genes have been discovered as being differently methylated, including IL6R, CAPN8, and DPP4. Comparing rheumatoid arthritis synovial fibroblast (RASF) DNA methylation with miRNA expression and RASF transcriptome data from the Gene Expression Omnibus (GEO), more than 200 of the 714 genes identified had an inverse expression. Moreover, several CpG sites have been detected to be hypermethylated with concomitantly reduced miRNA expression [80]. Histone modifications associated with RA have been less studied; although, an involvement of these epigenetic changes has been documented in RA pathogenesis. Dysregulated HDAC activity in RA PBMCs was not affected by conventional anti-TNF therapies whereas treatment with MI192, a HDAC2/3-selective inhibitor, reduced IL6 production in a dose-dependent manner, thus providing a novel therapeutic approach for RA [81]. Wendling et al. evaluated the relationship between Sirt1 activity/expression and IL-3 levels in PBMCs. High levels of serum IL-3 associated with decreased Sirt1 expression and increased apoptosis in patients with RA have been observed [82]. Kawabata et al. reported an increased HDAC1 expression by TNF- $\alpha$ supplementation in RA synovial fibroblasts [83-85]. HDACi showed anti-inflammatory properties in FLS attenuating disease in animal models of RA. An interesting small open-label trial of givinostat (a HDACi) in a similar disorder, juvenile idiopathic arthritis, outlined improvement in arthritis and a wide safety profile [86]. In RA synovial tissues, the equilibrium between HATs and HDACs activity is heavily disturbed owing to the soaring of HAT activity resulting in hyperacetylation [87]. An increase in IL6 expression by hyperacetylation of histone $\mathrm{H} 3$ has been found in synovial fibroblasts [88]. Ahmed et al. demonstrated that largazole, a marine-derived class I-selective $\mathrm{HDACi}$, provokes the suppression of the TNF $\alpha$-induced expression of the intracellular adhesion molecule-1 (ICAM-1) and the vascular adhesion molecule-1 (VCAM-1) in RASF, as well as in the reduction of the TNF $\alpha$-induced MMP2 activity. Additionally, largazole was shown to modulate expression levels of HDAC1, HDAC5, and HDAC6. Of particular interest is the role of HDAC6 in largazole-induced changes of ICAM-1 and VCAM-1 expression levels [89]. Studies trying to explain the effects of microRNAs on RA pathogenesis are emerging more and more in the recent literature. The upregulation of miR-146a with TNF- $\alpha$ and at the same time the downregulation of miR-363 and miR-498 has been found in $\mathrm{CD}^{+}$cells of RA patients [90]. Despite these pieces of evidence, various studies have shown that miR-146a and miR-155 were decreased in Treg cells after $\mathrm{T}$ cell stimulation in RA patients [91]. Additionally, the expression of miR-126a in RA turned out to be elevated, leading to hypomethylated promotors of CD11a and CD70 which in turn led to their overexpression [92]. Further, the increased expression of miR-21 resulted in Treg cell accumulation in synovial fibroblasts of patients suffering from RA [93].

\section{Systemic sclerosis (SSc)}

SSc is a rare and poorly understood autoimmune disease of the connective tissue leading to excessive collagen deposition in the skin and other organs often with a lethal outcome. Aberrant activation of fibroblasts and collagen secretion in SSc conduces to fibrosis. Like SLE, early studies have shown a link to $\mathrm{T}$ cell dysfunction and, in particular, autoreactive $\mathrm{T}$ cell transfer signals to surrounding fibroblasts inducing the deposit of collagen and initiation of fibrosis [94]. The hypomethylation of $\mathrm{CD} 4^{+}$cells, caused at least in part by the downregulation of DNMTs, determined the overexpression of several genes involved in disease progression [95]. Notably, the downregulation of functional demethylating enzymes such as DNMT1, MBD3, and MBD4 resulted in lower levels of methylation at the promoter sites of sensitive genes implicated in SS leading to the overexpression of $C D 40 L, C D 11 a$, and CD70 as a relevant feature of SSc [96-98]. The overexpression of the adaptive immune costimulatory molecule $C D 40 L$, which is crucial for the integrative role in fibrosis of SSc, is a clear sign of the disease in plasma and skin fibroblasts $[99,100]$. Furthermore, abrogation of $C D 40 / C D 40 L$ interaction reduces fibrosis in a SSc mouse model [101]. Recently, other 
pathways related to SSc have been discussed with particular emphasis on their epigenetic dysregulation mechanisms. One such pathway, Wnt, increases skin fibrosis in SSc patients [102]. Importantly, Dickkopf-1 and SFRP-1 are both hypermethylated in dermal fibroblasts and PBMCs in a mouse model of SSc. Thus, treatment with 5-azacytidine reduces Wnt signaling and deletes the fibrosis phenotype [103]. Likewise, inactivation of the collagen suppressor gene FLI1 by epigenetic hypermethylation reduces the expression of type I collagen in fibroblasts from SSc patients [104]. As aforementioned, fibroblasts play a pivotal role in SSc pathogenesis due to collagen and extracellular matrix component overproduction. As a consequence, various cytokines may be produced to dysregulated immune cells further [105]. Reduced H3K27me3 levels were observed as an important posttranslational modification of $\mathrm{CD}^{+}$cells in $\mathrm{SSc}$ leading to the accumulation of the jumonij demethylase JMJD3 in the aforementioned cells [106]. Similarly, to SLE, several histone modifications have been noted in SSc. Both H3 and H4 acetylation is reduced in SSc fibroblasts [104]. Indeed, the reduced expression of collagen in cultured SSc fibroblasts, as well as fibrosis in animal models, have been reported following HDACi treatment [107, 108]. MicroRNAs have been implicated in SSc concerning to dysregulated fibrosis. In details, miR-29a is decreased in SSc fibroblasts leading to a reduction in Co1 1 and 3 expressions [109]. MiR-29a can avoid pulmonary fibrosis and its knock-down increases pro-fibrotic TGF- $\beta$ and PDGF-B level. [110]. MiR-21 is regulated by TGF- $\beta$ and targets smad-7, a key profibrotic gene $[111,112]$. At last, miR-155 mediates fibrosis by recruiting keratinocyte growth factor, and overexpressed miR-196 reduces collagen levels by regulating collagen $1[113,114]$.

\section{Sjogren's syndrome (SS)}

SS is an autoimmune disease affecting salivary and tear glands of unknown origin resulting in eye and mouth dryness. SS is a quite prevalent autoimmune disorder affecting about four million people in the USA. This autoimmune illness is associated with autoantibody production in the blood that is directed against various tissues of the body leading to an inflammatory response. Similarly to other autoimmune diseases, reduced DNA methylation of immune cells is one of the most studied epigenetic marks in SS. Yin et al. found that the $\mathrm{T}$ cell costimulatory gene CD70 overexpression on $\mathrm{CD}^{+} \mathrm{T}$ cells is due to the hypomethylation of CD70 promoterin SS patients [115]. By contrast, lower expression levels of FOXP3 in SS CD4 ${ }^{+} \mathrm{T}$ cells have been correlated with DNA hypermethylation [116]. A genome-wide DNA methylation study in naïve $\mathrm{CD} 4^{+} \mathrm{CD} 45 \mathrm{RA}^{+}$cells resulted in the identification of 553 methylated CpG sites. LTA, encoding lymphotoxin $\alpha$, has been found overexpressed in both salivary gland tissue and sera of SS patients [117]. Therefore, its downregulation in the salivary gland of SS mouse model prevents the development of SS. Next, a broader comprehensive study of genome-wide DNA methylation patterns was carried out in whole blood, peripheral $\mathrm{CD} 19^{+} \mathrm{B}$ cells, and minor salivary glands [118]. Differentially hypomethylated sites were identified in type I IFN-induced genes such as $M X 1$, IFI44L, PARP9, and IFITM1. The hypomethylation of their promoter in SS B cells was linked to elevated mRNA expression levels. Several other genes have been noted to be differentially methylated, including hypomethylated STAT1, IFI44L, IFITM1, and USP8. Conversely, the RUNX1 gene, an important transcription factor involved in $\mathrm{T}$ cell development, was hypermethylated among SS patients. Due to reduced expression of DNMT1 and an increase in GADD45 $\alpha$, epithelial cells from the salivary gland (SGEC) showed global hypomethylation in SS patients. This finding might be associated with infiltrating B lymphocytes. Increased DNA methylation levels in SGEC from SS patients have been reported after the administration of the anti-CD20 monoclonal antibody rituximab [119]. Konsta et al. showed that reduced DNA methylation levels in minor salivary glands might be correlated with overexpression of the epithelial protein cytokeratin-19 (gene KRT19) in glandular acini, while high methylation levels resulted in low levels of this protein proven by immunohistochemical analyses [120]. A follow-up study of the same authors proved their concept as the treatment of a human salivary gland cell line with the DNMT inhibitor 5-azacytidine led to KRT19 mRNA and cytokeratin-19 protein overexpression [121]. To sum up, altered DNA methylation patterns in SGEC may be an important factor in SS pathophysiology probably at least partially via the controlling of the KRT19/cytokeratin-19 expression. Actually, no large-scale studies of histone modifications as well as of lncRNAs have been carried out in SS. Increased miR-146a expression has been observed in PBMCs during the onset of SS [122].

\section{Organ-specific autoimmune diseases}

Organ-specific autoimmune diseases, as suggested by the name, are immune response attacks of the body towards healthy cells of a specific organ system occurring as a result of either genetic predisposition or environmental influences or a mixture of both. Many efforts have been performed to understand the inherited autoimmune responses [123]. A large number of polymorphic genes are key players in the genesis of these chronic autoimmune disorders. To date, most details in these processes still need to be understood better even though a large number these genes are apparently 
involved in setting a threshold for an immune response. Organ-specific autoimmune diseases are usually related to specific human leukocyte class II antigens [124]. In many cases, specific antibodies may be found in patients with chronic and apparently "idiopathic" organ-specific autoimmune diseases. Basically, these antibodies bind to self-antigens in the organ cells or directly on cells, thus leading to their destruction [125]. Examples are the autoimmune thyroid diseases (AITD) and type 1 diabetes (T1D), in which ANA attack the thyroid gland and the immune system which compromises the pancreas, respectively [126, 127]. Normally, the regulation of the autoimmune process involves antigen-specific regulatory cells.

Anti-inflammatory cytokines such as IL-10 and TGF- $\beta$ are also involved. Up to now, blockers of the immune response produced a greater success in the clinical use than treatments exploiting natural immune regulation. In fact, blocking the immune response is crucial in autoimmunity, even though immunosuppression leads to various side effects, including the reactivation of latent infections and the reduction of immunosurveillance. Thus, antigen-specific immune therapeutical options, instead of rather unspecific therapies targeting the immune system, are an important goal to reach towards the treatment of autoimmune disorders. Over the last decade, scientists figured out that epigenetic changes are clearly correlated with organ-specific autoimmune diseases (Table 3). With the aim to better elucidate mechanisms behind these organ-specific diseases, several studies have been carried out using approved epi-drugs $[128,129]$ (Table 4). Importantly, the discovery of an epigenetic therapy to treat such autoimmune disorders may unearth potential biomarkers for disease diagnosis and prediction.

\section{Autoimmune thyroid diseases (AITDs)}

AITDs are a form of autoimmune diseases mediated by $B$ and $T$ cells. The two main clinical manifestations of AITDs are Flajani-Basedow-Graves' disease or Graves' disease (GD) and Hashimoto's thyroiditis (HT) [130, 131]. HT led to hypothyroidism by cell-mediated autoimmune destruction, while in GD specific autoantibodies against the thyroid stimulation hormone receptor result in hyperthyroidism [132]. Recent literature shed light on the epigenetic mechanisms involved in the pathogenesis of AITD. DNA methylation, histone modifications, and lncRNA have been deeply analyzed in AITDs. However, the clinical utility of epigenetic modulation still remains elusive. Recent findings confirmed that DNA methylation is also in AITDs setting a very crucial epigenetic mechanism. Global DNA hypomethylation was observed in AITD patients, which may result in overexpressed genes important for a correct immune function, or for the activation of immune cells, ultimately leading into an autoimmune attack towards thyroid tissues [133, 134]. In a genome-wide study, Cai et al. have detected in GD patients more than 200 hyperand hypo-methylated genetic regions, such as ICAM1, which partly controls cell antigen processing and presentation; DNMT1; and MECP2 genes [133]. Via epigenetic profiling in $\mathrm{CD}^{+}$and $\mathrm{CD}^{+}$cells from GD patients, hypermethylated gene loci of ICAM1, CD247, and CTLA4 associated with $\mathrm{T}$ cell receptor signaling were observed. $[133,134]$. Furthermore, hypermethylation of the first intron area in the TSHR gene confirmed that methylation is involved in the development of AITDs. However, DNA hypomethylation levels and susceptibility to AITDs have been correlated to the presence of genetic polymorphisms of DNA methylation-regulatory genes, such as DNMT1 or methionine synthase reductase $(M T R R)$ [135]. Histone modifications play a key role in AITDs, but the exact mechanism(s) in modulating immune tolerance in AITDs is still not fully elucidated. Yan et al. described higher levels of HDAC1 and HDAC2 mRNAs in GD patients thus histone $\mathrm{H} 4$ acetylation levels in peripheral blood mononuclear cells of GD patients were lower if compared to those observed in healthy control patient. These results underline the potential importance of aberrant histone modifications in GD patients [24]. In patients with GD, $\mathrm{CD}^{+}$and $\mathrm{CD}^{+}$cells were presented higher levels of H3K4me3 and H3K27Ac histone marks [134]. IFN- $\alpha$, an important cytokine secreted during viral infections, has been identified to be able to lead to higher mono and trimethylation levels of H3K4m in thyroid cells [136]. As previously seen for DNA methylation, genetic polymorphism of histone-modifying genes may result in various malfunctions, and/or other further aberrant

Table 3 Main epigenetic modifications in autoimmune thyroid diseases (AITDs) and type 1 diabetes (T1D)

\begin{tabular}{|c|c|c|c|}
\hline Autoimmune disease & DNA methylation & Histone modification & miRNA \\
\hline AITD & $\uparrow \top$ cells [133-135] & $\begin{array}{l}\downarrow \mathrm{H} 3, \mathrm{H} 4 \text { acetylation } \\
\text { IFN-a enhances } \mathrm{H} 3 \mathrm{~K} 4 \text { methylation } \\
{[24,134,136,137]}\end{array}$ & $\begin{array}{l}\downarrow \text { miR-155-5p, } \\
\downarrow \text { miR-146a-5p, } \\
\downarrow \text { miR-125a-3p } \\
\downarrow \text { miR-197a-3p } \\
\text { Fibroblasts: } \\
\uparrow \text { miR-21-5p [138-141] }\end{array}$ \\
\hline T1D & $\begin{array}{l}\uparrow T \text { cell } \\
\uparrow \text { FOXP3 }[150,156,157]\end{array}$ & $\uparrow \mathrm{H3}$ acetylation [159] & $\begin{array}{l}\uparrow \operatorname{miR}-510 \\
\downarrow \text { miR-342, } \downarrow \text { miR-191 [160] }\end{array}$ \\
\hline
\end{tabular}


Table 4 Effects of Epi-drugs on autoimmune disorders discussed in this review

\begin{tabular}{|c|c|c|c|c|c|}
\hline $\begin{array}{l}\text { Autoimmune } \\
\text { disorder }\end{array}$ & Epi-drug & Chemical structure & $\begin{array}{l}\text { Target } \\
\text { specificity }\end{array}$ & Autoimmune pathways involved & Ref. \\
\hline SLE, SSC, SS & $\begin{array}{l}\text { Azacytidine } \\
\text { (5-AZA) } \\
\text { FDA approved, } \\
2004\end{array}$ & & DNMTi & $\begin{array}{l}\text { LFA-1 (CD11a/CD18) } \\
\text { ITGAL, IL-6, Wnt pathway, SFRP-1, } \\
\text { Dickkoft-1, KRT19, cytokeratin-19 protein }\end{array}$ & $\begin{array}{l}{[56,103,} \\
121]\end{array}$ \\
\hline SLE & Procainamide & & DNMT1i & CD70, LFA-1, IL-6 & {$[56,59]$} \\
\hline SLE & Hydralazine & & DNMTi & CD70 and other costimulatory proteins & {$[56,59]$} \\
\hline SLE, T1D & $\begin{array}{l}\text { Trichostatin A } \\
\text { (TSA) }\end{array}$ & & Pan $\mathrm{HDACi}$ & $\begin{array}{l}\text { Acid nuclear transport proteins, } \\
\text { cytoskeleton proteins, } \\
\text { IFN- } \gamma \text { production, transcription } \\
\text { activity of Tbx } 21 \text { in T lymphocytes }\end{array}$ & {$[67,159]$} \\
\hline SLE & $\begin{array}{l}\text { Vorinostat } \\
\text { (SAHA) } \\
\text { FDA approved, } \\
2006\end{array}$ & & Pan $\mathrm{HDACi}$ & $\begin{array}{l}\text { Acid nuclear transport proteins, } \\
\text { cytoskeleton proteins }\end{array}$ & {$[67]$} \\
\hline RA & $\begin{array}{l}\text { Givinostat } \\
\text { (ITF2357) }\end{array}$ & & $\begin{array}{l}\text { Pan } \\
\text { HDACi }\end{array}$ & Arthritic components, T cells & {$[86]$} \\
\hline RA & Largazole & & $\begin{array}{l}\text { Class I } \\
\text { HDACi }\end{array}$ & $\begin{array}{l}\text { ICAM-1, VCAM-1, MMP2, } \\
\text { TNFa, p38, AKT pathway }\end{array}$ & [89] \\
\hline RA & $\begin{array}{l}\text { Romidepsin } \\
\text { (FK228, } \\
\text { Depsipeptide) } \\
\text { FDA approved, } \\
2009\end{array}$ & & $\begin{array}{l}\text { Class I } \\
\text { HDACi }\end{array}$ & $\begin{array}{l}\text { TNFa, IL-1 } \beta, \text { p16LNK4a, } \\
\text { p21 (WAF1/Cip1) }\end{array}$ & [84] \\
\hline RA & Ml192 & & $\begin{array}{l}\mathrm{HDAC2} / 3 \\
\text { inhibitor }\end{array}$ & IL6 & [81] \\
\hline
\end{tabular}

histone modifications. Sarumaru et al. demonstrated that rs3758391 and rs4746720 in the SIRT1 gene were linked to higher titers of autoantibodies in AITD affected patients [137]. As previously illustrated for other autoimmune disorders, microRNAs actively modulate in various circumstances the differentiation or activation of immune cells and immune response. Two of the most studied miRNA are miR-155-5p and miR-146a-5p, whose overexpression is believed to break immune tolerance thus fostering the development of autoimmune diseases. For example, GD and HT patients exhibit markedly lower levels of miR-155-5p and miR-146a-5p in the thyroid tissues [138]. Although many research's efforts showed the potential role of other microRNAs, such as miR-125a-3p, miR-197a-3p, miR-22-3p, and miR-183-5p, only a small number of studies investigated their clinical relevance as diagnostic biomarkers [139-141]. Another epigenetic process called X chromosome inactivation (XCI) has also been discussed in correlation with AITDs [142-144]. X chromosomes are randomly inactivated in females 
resulting in transcriptional silencing of one of the $\mathrm{X}$ chromosomes $[145,146]$. Indeed, AITDs are more often observed in females, confirming the compelling role of $\mathrm{XCI}$ in these autoimmune disorders. Brix et al. demonstrated that skewed $\mathrm{X}$ chromosome inactivation in female twins with GD and HT was significantly higher than in the control populations, suggesting a probable role of XCI in the etiology of AITD [147]. However, Ishido et al. reported no apparent difference between AITD cases and controls. By contrast, a notable relationship between skewed XCI inactivation and the prognosis of GD and HT was observed [148].

\section{Type 1 diabetes (T1D)}

T1D is a chronic autoimmune disease that involves $\beta$ cell destruction together with a strong inflammatory response. The incidence of diabetes is on the rise worldwide becoming one of the major causes of death. In more detail, the body's own immune system is destroying the insulin-producing pancreatic $\beta$ cells first lowering and ultimately ceasing the ability of the pancreas to produce insulin. To date, the disease cannot be cured, although exogenous insulin therapy still remains a life-saving therapy. The destructive process causing T1D is thought to have a pertinent adaptive autoimmune component. In fact, persuasive shreds of evidence suggested that aberrant epigenetic modifications are involved in T1D pathogenesis. The epigenetic involvement in T1D has been nicely reviewed recently [149]. However, environmental factors, in different models of diabetes, influence epigenetic changes and consequently contribute significantly to altered gene expression relevant in T1D development and progression. Over the last decade, some studies have reported that DNA methylation, histone modifications, and noncoding RNAs are considered to have a crucial role in T1D. Again, a genome-wide DNA methylation identified SNP-CpG methylation patterns as potentially relevant for the genetic association of insulin expression and/or secretion in human pancreatic islets [150]. In more detail, candidate genes, such as GPX7, GSTT1, and SNX19, are known to possess a direct influence on various biological processes regarding proliferation and apoptosis in pancreatic $\beta$ cells. Another study in mouse models also confirmed the implication of epigenetic changes in insulin secretion and diabetes risk [151]. Patients with T1D, compared to the healthy controls, exhibited cell-type-specific gene regulatory circuits crucial for immune cell metabolism and the cell cycle. The latter includes mTOR signaling pathway implicated in the development of diabetes-associated damage [152]. It is believed that epigenetic alteration in diabetes might be the cause for an increased risk for the development and progression of vascular complications. Very likely, these effects are mediated through histone methyltransferases which boost the pro-inflammatory networks implicated in vascular injury [153-155]. Hypermethylated regions of FOXP3 in $\mathrm{CD} 4^{+}$cells in T1D resulted in decreased FOXP3 expression and reduced production of regulatory $\mathrm{T}$ cells [156]. Additionally, Wang et al. supported the idea of the FOXP3 involvement as its gene hypermethylation was induced by Toll-like receptor 9 (TLR9) in association with a reduced binding activity of interferon regulator factor 7 (IRF-7) [157]. About histone modifications, increased $\mathrm{H} 3 \mathrm{~K} 9 \mathrm{me} 2$ levels in the promoter of CLTA4, a T1D susceptibility gene, has been correlated with T cell activation [158]. Moreover, Patel et al. suggested that TSA, a well-known HDACi, excites IFN- $\gamma$ production and increases the transcription activity of Tbx21 in $\mathrm{T}$ lymphocytes, alleviating the inflammatory damage of islets [159]. Since T1D shows a broad range of miRNA expression profiles, some miRNAs have been associated with T1D. Upregulated miR-510, as well as the downregulation of miR-342 and miR-191, have been described in T1D. Furthermore, once Treg cells are compared with other types of effector $\mathrm{T}$ cells, data showed a substantial change in the expression patterns of miR-146a in conjugation with a decreased expression of eight targeting miRNAs (20b, 31, 99a, 100, 125b, 151, 335, and 365) thus demonstrating the involvement of miRNAs in T1D patients' Treg cells [160].

\section{Benefits and risk of epigenetic therapy}

As we have seen in the previous sections, mainly old well-studied and often already approved epigenetic modulators have been used in the context of autoimmune diseases [56, 59, 67, 81, 84, 86, 89, 103, 121, 159]. These first-generation molecules have been originally developed as anti-tumor therapy. They often show heavy side effects by mechanism, which are tolerable in cancer, but not in other diseases $[9,19]$. This point is one major drawback and risk of the studies currently present in literature. The main challenge for researchers is not only to understand better the role of epigenetics in autoimmune disorders also with the help of epigenetic modulators, but also to develop novel specific targeted therapies. Interestingly, novel second or third generation epigenetic modulators, which often have a better selectivity and safety profile, have been used in other medical conditions but have not yet been applied in immunotherapy approaches [18, 161]. In our view, benefits outweigh the risks as novel innovative treatments are needed, but researchers should proceed with care considering the selectivity and safety profile of their potential treatments already at an early stage of the therapy development. 


\section{Conclusions}

This work has been focused on epigenetic mechanisms regulating several autoimmune disorders with the aim to provide new therapeutic ideas in this area of interest (Fig. 1). The link between epigenetics and autoimmunity has been widely documented in the literature; although, more and more extensive studies are required to better understand the influence of these modifications in the different autoimmune disorders. A deeper exploration of the complex epigenetic interactions may be useful for the development of promising treatment strategies targeting the epigenome. The fundamental work of Farh et al. in 2015 described a fine-mapping algorithm to identify non-coding genetic variants that could underlie autoimmune diseases from genotyping data [162]. However, to date, there is still a lot of research necessary in order to provide effective healthcare solutions for such diseases, such as an adequate choice of treatment and a precise prediction of treatment outcomes. Epigenetics will very likely aid to provide further progress in the field of autoimmunity. Until now, only a few studies have been carried out to examine the clinical applicability of epigenetics and its modulators in such autoimmune diseases. Keeping this concept in mind, more comprehensive and more accessible technologies are recommended to promote advances in the therapeutics leading to prevention by early interventions and reducing both costs and patient morbidity. Taken together, the future of epigenetics in autoimmunity is rapidly increasing. However, it still needs an in-depth investigation to allow novel potential therapeutic opportunities, better than those currently used.

\begin{abstract}
Abbreviations
AITD: Autoimmune thyroid diseases; DNMTs: DNA methyltransferases; GD: Graves' disease; GEO: Gene Expression Omnibus; HATs: Histone acetyltransferases; HDACi: Histone deacetylases inhibitors; HDACs: Histone deacetylases; HT: Hashimoto thyroiditis; ICAM-1: Intracellular adhesion molecule-1; IF: Immunofluorescence; IRF-7: Interferon regulator factor 7; LincRNAs: Long intergenic noncoding RNAs; LncRNAs: Long noncoding RNAs; LRA: Largazole; miRNAs: microRNAs; MTRR: Methionine synthase reductase; OA: Osteoarthritis; PBMC: Peripheral blood mononuclear cells; PP2Ac: Protein phosphatase 2A; PRF1: Perforin; RA: Rheumatoid arthritis; RASF: Rheumatoid arthritis synovial fibroblasts; RFX1: Regulatory factor X1; SAM: S-adenosyl-methionine; SGEC: Salivary gland; SLE: Systemic lupus erythematosus; SS: Sjogren's syndrome; SSc: Systemic sclerosis; T1D: Type 1 diabetes; TLR9: Toll-like receptor 9; TSA: Trichostatin A; VCAM-1: Vascular adhesion molecule-1; XCl: X chromosome inactivation
\end{abstract}

\section{Acknowledgments}

Not applicable.

\section{Funding}

This work was supported by funds from IIT-Sapienza Project (R.M.), the COST action CM1406 Epigenetic Chemical Biology (A.M.), PRIN 2015 (prot. 20152TE5PK) (A.M.), AIRC 2016 (n. 19162) (A.M.), PE-2013-02355271 (A.M.) and $\mathrm{NIH}$ (n. R01GM114306) (A.M.). The research for this paper was financially supported by the Italian Ministry of Health and Fondazione Roma.

Availability of data and materials Not applicable.

\section{Authors' contributions}

$\mathrm{RM}, \mathrm{CZ}$, and $\mathrm{AM}$ researched the literature and drafted the manuscript. ST, MR, MA, AG, and AM critically reviewed and edited the work. All authors read and approved the final manuscript.

Ethics approval and consent to participate

Not applicable.

Consent for publication

Not applicable.

\section{Competing interests}

The authors declare that they have no competing interests.

\section{Publisher's Note}

Springer Nature remains neutral with regard to jurisdictional claims in published maps and institutional affiliations.

\section{Author details}

${ }^{1}$ Department of Chemistry and Technologies of Drugs, Sapienza University of Rome, P.le A. Moro 5, 00185 Rome, Italy. ${ }^{2}$ Center for Life Nano

Science@Sapienza, Italian Institute of Technology, Viale Regina Elena 291, 00161 Rome, Italy. ${ }^{3}$ Department of Sense Organs, Sapienza University of Rome, P.le A. Moro 5, 00185 Rome, Italy. ${ }^{4}$ IRCCS G.B. Bietti Foundation, Via Livenza, 3, 00198 Rome, Italy. ${ }^{5}$ Pasteur Institute - Cenci Bolognetti Foundation, Sapienza Università di Roma, P.le Aldo Moro 5, 00185 Rome, Italy.

Received: 23 December 2018 Accepted: 12 February 2019

Published online: 26 February 2019

\section{References}

1. Bird A. Perceptions of epigenetics. Nature. 2007:447(7143):396-8. https://doi. org/10.1038/nature05913.

2. Moosavi A, Motevalizadeh AA. Role of epigenetics in biology and human diseases. Iran Biomed J. 2016;20(5):246-58.

3. Mazzone R, Zwergel C, Mai A, Valente S. Epi-drugs in combination with immunotherapy: a new avenue to improve anticancer efficacy. Clin Epigenetics. 2017;9:59. https://doi.org/10.1186/s13148-017-0358-y.

4. Du J, Johnson LM, Jacobsen SE, Patel DJ. DNA methylation pathways and their crosstalk with histone methylation. Nat Rev Mol Cell Biol. 2015;16(9): 519-32. https://doi.org/10.1038/nrm4043.

5. Torres IO, Fujimori DG. Functional coupling between writers, erasers and readers of histone and DNA methylation. Curr Opin Struct Biol. 2015;35:68-75. https://doi.org/10.1016/j.sbi.2015.09.007.

6. Schubeler D. Function and information content of DNA methylation. Nature. 2015;517(7534):321-6. https://doi.org/10.1038/nature14192.

7. Bjornsson HT, Fallin MD, Feinberg AP. An integrated epigenetic and genetic approach to common human disease. Trends Genet. 2004;20(8):350-8. https://doi.org/10.1016/j.tig.2004.06.009.

8. Vaissiere T, Sawan C, Herceg Z. Epigenetic interplay between histone modifications and DNA methylation in gene silencing. Mutat Res. 2008; 659(1-2):40-8. https://doi.org/10.1016/j.mrrev.2008.02.004.

9. Zwergel C, Valente S, Mai A. DNA methyltransferases inhibitors from natural sources. Curr Top Med Chem. 2016;16(7):680-96. https://doi.org/10.2174/ 1568026615666150825141505.

10. Jurkowski TP, Jeltsch $A$. On the evolutionary origin of eukaryotic DNA methyltransferases and Dnmt2. PLoS One. 2011;6(11):e28104. https://doi. org/10.1371/journal.pone.0028104.

11. Jurkowska RZ, Jeltsch A. Mechanisms and biological roles of DNA methyltransferases and DNA methylation: from past achievements to future challenges. Adv Exp Med Biol. 2016;945:1-17. https://doi.org/10.1007/978-3319-43624-1_1.

12. Wadhwa E, Nicolaides T. Bromodomain inhibitor review: Bromodomain and extra-terminal family protein inhibitors as a potential new therapy in central nervous system tumors. Cureus. 2016;8(5):e620. https://doi.org/10.7759/ cureus.620.

13. Chen Z, Miao F, Paterson AD, Lachin JM, Zhang L, Schones DE, et al. Epigenomic profiling reveals an association between persistence of DNA methylation and metabolic memory in the DCCT/EDIC type 1 diabetes 
cohort. Proc Natl Acad Sci U S A. 2016;113(21):E3002-11. https://doi.org/10 1073/pnas.1603712113.

14. Paul DS, Teschendorff AE, Dang MA, Lowe R, Hawa MI, Ecker S, et al. Increased DNA methylation variability in type 1 diabetes across three immune effector cell types. Nat Commun. 2016;7:13555. https://doi.org/10 1038/ncomms 13555

15. Tahara T, Hirata I, Nakano N, Nagasaka M, Nakagawa Y, Shibata T, et al. Comprehensive DNA methylation profiling of inflammatory mucosa in ulcerative colitis. Inflamm Bowel Dis. 2017;23(1):165-73. https://doi.org/10. 1097/MIB.0000000000000990.

16. Lawrence M, Daujat S, Schneider R. Lateral thinking: how histone modifications regulate gene expression. Trends Genet. 2016;32(1):42-56. https://doi.org/10.1016/j.tig.2015.10.007.

17. Venkatesh $\mathrm{S}$, Workman JL. Histone exchange, chromatin structure and the regulation of transcription. Nat Rev Mol Cell Biol. 2015;16(3):178-89. https:// doi.org/10.1038/nrm3941

18. Dieker J, Muller S. Epigenetic histone code and autoimmunity. Clin Rev Allergy Immunol. 2010;39(1):78-84. https://doi.org/10.1007/s12016-0098173-7.

19. Zwergel C, Valente S, Jacob C, Mai A. Emerging approaches for histone deacetylase inhibitor drug discovery. Expert Opin Drug Discovery. 2015; 10(6):599-613. https://doi.org/10.1517/17460441.2015.1038236.

20. Chistiakov DA, Orekhov AN, Bobryshev YV. Treatment of cardiovascular pathology with epigenetically active agents: focus on natural and synthetic inhibitors of DNA methylation and histone deacetylation. Int J Cardiol. 2017; 227:66-82. https://doi.org/10.1016/j.ijcard.2016.11.204.

21. Falkenberg KJ, Johnstone RW. Histone deacetylases and their inhibitors in cancer, neurological diseases and immune disorders. Nat Rev Drug Discov. 2014;13(9):673-91. https://doi.org/10.1038/nrd4360.

22. Akimova T, Beier UH, Liu Y, Wang L, Hancock WW. Histone/protein deacetylases and T-cell immune responses. Blood. 2012;119(11):2443-51. https://doi.org/10.1182/blood-2011-10-292003.

23. Panella S, Marcocci ME, Celestino I, Valente S, Zwergel C, Li Puma DD, et al. MC1568 inhibits HDAC6/8 activity and influenza a virus replication in lung epithelial cells: role of Hsp90 acetylation. Future Med Chem. 2016;8(17): 2017-31. https://doi.org/10.4155/fmc-2016-0073

24. Yan N, Zhou JZ, Zhang JA, Cai T, Zhang W, Wang Y, et al. Histone hypoacetylation and increased histone deacetylases in peripheral blood mononuclear cells from patients with graves' disease. Mol Cell Endocrinol. 2015:414:143-7. https://doi.org/10.1016/.mce.2015.05.037.

25. Cheng F, Lienlaf M, Wang HW, Perez-Villarroel P, Lee C, Woan K, et al. A novel role for histone deacetylase 6 in the regulation of the tolerogenic STAT3/L-10 pathway in APCs. J Immunol. 2014;193(6):2850-62. https://doi. org/10.4049/jimmunol.1302778.

26. Rinn JL, Chang HY. Genome regulation by long noncoding RNAs. Annu Rev Biochem. 2012;81:145-66. https://doi.org/10.1146/annurev-biochem-051410092902.

27. Khalil AM, Guttman M, Huarte M, Garber M, Raj A, Rivea Morales D, et al. Many human large intergenic noncoding RNAs associate with chromatin-modifying complexes and affect gene expression. Proc Natl Acad Sci U S A. 2009;106(28):11667-72. https://doi.org/10.1073/pnas. 0904715106.

28. Guttman M, Amit I, Garber M, French C, Lin MF, Feldser D, et al. Chromatin signature reveals over a thousand highly conserved large non-coding RNAs in mammals. Nature. 2009;458(7235):223-7. https://doi.org/10.1038/ nature07672.

29. Jonas $\mathrm{S}$, Izaurralde $\mathrm{E}$. Towards a molecular understanding of microRNAmediated gene silencing. Nat Rev Genet. 2015;16(7):421-33. https://doi.org/ $10.1038 /$ nrg3965.

30. Vicente R, Noel D, Pers YM, Apparailly F, Jorgensen C. Deregulation and therapeutic potential of microRNAs in arthritic diseases. Nat Rev Rheumatol. 2016;12(8):496. https://doi.org/10.1038/nrrheum.2016.119.

31. Chen JQ, Papp G, Szodoray P, Zeher M. The role of microRNAs in the pathogenesis of autoimmune diseases. Autoimmun Rev. 2016;15(12):117180. https://doi.org/10.1016/j.autrev.2016.09.003.

32. Fedeli M, Riba M, Garcia Manteiga JM, Tian L, Vigano V, Rossetti G, et al. miR-17 approximately 92 family clusters control iNKT cell ontogenesis via modulation of TGF-beta signaling. Proc Natl Acad Sci U S A. 2016;113(51): E8286-E95. https://doi.org/10.1073/pnas.1612024114.

33. Jacobson DL, Gange SJ, Rose NR, Graham NM. Epidemiology and estimated population burden of selected autoimmune diseases in the United States.
Clin Immunol Immunopathol. 1997;84(3):223-43. https://doi.org/10.1006/ clin.1997.4412.

34. Helmick CG, Felson DT, Lawrence RC, Gabriel S, Hirsch R, Kwoh CK, et al. Estimates of the prevalence of arthritis and other rheumatic conditions in the United States. Part I Arthritis Rheum. 2008;58(1):15-25. https://doi.org/ 10.1002/art.23177.

35. Walsh SJ, Rau LM. Autoimmune diseases: a leading cause of death among young and middle-aged women in the United States. Am J Public Health. 2000;90(9):1463-6. https://doi.org/10.2105/AJPH.90.9.1463.

36. Marie I, Hachulla E, Hatron PY, Hellot MF, Levesque H, Devulder B, et al. Polymyositis and dermatomyositis: short term and longterm outcome, and predictive factors of prognosis. J Rheumatol. 2001;28(10):2230-7.

37. Meroni PL, Schur PH. ANA screening: an old test with new recommendations. Ann Rheum Dis. 2010;69(8):1420-2. https://doi.org/10. 1136/ard.2009.127100.

38. Kavanaugh A, Tomar R, Reveille J, Solomon DH, Homburger HA. Guidelines for clinical use of the antinuclear antibody test and tests for specific autoantibodies to nuclear antigens. American College of Pathologists. Arch Pathol Lab Med. 2000;124(1):71-81. https://doi.org/10.1043/00039985(2000)124<0071:GFCUOT>2.0.CO;2.

39. Hudson M, Pope J, Mahler M, Tatibouet S, Steele R, Baron M, et al. Clinical significance of antibodies to Ro52/TRIM21 in systemic sclerosis. Arthritis Res Ther. 2012;14(2):R50. https://doi.org/10.1186/ar3763.

40. Higgs BW, Zhu W, Richman L, Fiorentino DF, Greenberg SA, Jallal B, et al. Identification of activated cytokine pathways in the blood of systemic lupus erythematosus, myositis, rheumatoid arthritis, and scleroderma patients. Int J Rheum Dis. 2012;15(1):25-35. https://doi.org/10.1111/j.1756-185X.2011.01654.x.

41. Cho JH, Gregersen PK. Genomics and the multifactorial nature of human autoimmune disease. N Engl J Med. 2011;365(17):1612-23. https://doi.org/ 10.1056/NEJMra1100030.

42. Davidson A, Diamond B. Autoimmune diseases. N Engl J Med. 2001;345(5): 340-50. https://doi.org/10.1056/NEJM200108023450506.

43. Cotsapas C, Voight BF, Rossin E, Lage K, Neale BM, Wallace C, et al. Pervasive sharing of genetic effects in autoimmune disease. PLoS Genet. 2011;7(8): e1002254. https://doi.org/10.1371/journal.pgen.1002254.

44. Hudson M, Rojas-Villarraga A, Coral-Alvarado P, Lopez-Guzman S, Mantilla $\mathrm{RD}$, Chalem $\mathrm{P}$, et al. Polyautoimmunity and familial autoimmunity in systemic sclerosis. J Autoimmun. 2008;31(2):156-9. https://doi.org/10.1016/j. jaut.2008.05.002

45. Jeffries MA, Sawalha AH. Autoimmune disease in the epigenetic era: how has epigenetics changed our understanding of disease and how can we expect the field to evolve? Expert Rev Clin Immunol. 2015;11(1):45-58. https://doi.org/10.1586/1744666X.2015.994507.

46. Strickland FM, Richardson BC. Epigenetics in human autoimmunity. Epigenetics in autoimmunity - DNA methylation in systemic lupus erythematosus and beyond. Autoimmunity. 2008;41(4):278-86. https://doi. org/10.1080/08916930802024616.

47. Brooks WH, Le Dantec C, Pers JO, Youinou P, Renaudineau Y. Epigenetics and autoimmunity. J Autoimmun. 2010;34(3):J207-19. https://doi.org/10. 1016/j.jaut.2009.12.006

48. Meda F, Folci M, Baccarelli A, Selmi C. The epigenetics of autoimmunity. Cell Mol Immunol. 2011;8(3):226-36. https://doi.org/10.1038/cmi.2010.78.

49. Coit P, Yalavarthi S, Ognenovski M, Zhao W, Hasni S, Wren JD, et al. Epigenome profiling reveals significant DNA demethylation of interferon signature genes in lupus neutrophils. J Autoimmun. 2015;58:59-66. https:// doi.org/10.1016/j.jaut.2015.01.004

50. Richardson B. Primer: epigenetics of autoimmunity. Nat Clin Pract Rheumatol. 2007;3(9):521-7. https://doi.org/10.1038/ncprheum0573.

51. Yung RL, Quddus J, Chrisp CE, Johnson KJ, Richardson BC. Mechanism of drug-induced lupus. I. Cloned Th2 cells modified with DNA methylation inhibitors in vitro cause autoimmunity in vivo. J Immunol. 1995;154(6):3025-35.

52. Quddus J, Johnson KJ, Gavalchin J, Amento EP, Chrisp CE, Yung RL, et al. Treating activated CD4+ T cells with either of two distinct DNA methyltransferase inhibitors, 5-azacytidine or procainamide, is sufficient to cause a lupus-like disease in syngeneic mice. J Clin Invest. 1993;92(1):38-53. https://doi.org/10.1172/JCl116576.

53. Richardson B. Effect of an inhibitor of DNA methylation on T cells. II. 5Azacytidine induces self-reactivity in antigen-specific T4+ cells. Hum Immunol. 1986;17(4):456-70. https://doi.org/10.1016/0198-8859(86)90304-6.

54. Richardson BC, Liebling MR, Hudson JL. CD4+ cells treated with DNA methylation inhibitors induce autologous B cell differentiation. Clin 
Immunol Immunopathol. 1990;55(3):368-81. https://doi.org/10.1016/00901229(90)90125-A.

55. Lu Q, Kaplan M, Ray D, Ray D, Zacharek S, Gutsch D, et al. Demethylation of ITGAL (CD11a) regulatory sequences in systemic lupus erythematosus. Arthritis Rheum. 2002;46(5):1282-91. https://doi.org/10. 1002/art.10234.

56. Lu Q, Wu A, Tesmer L, Ray D, Yousif N, Richardson B. Demethylation of CD40LG on the inactive $X$ in T cells from women with lupus. J Immunol. 2007;179(9):6352-8. https://doi.org/10.4049/jimmunol.179.9.6352.

57. Zhao M, Liu Q, Liang G, Wang L, Luo S, Tang Q, et al. E4BP4 overexpression: a protective mechanism in CD4+ T cells from SLE patients. J Autoimmun. 2013;41:152-60. https://doi.org/10.1016/j.jaut.2013.01.004.

58. Sugita K, Torimoto Y, Nojima Y, Daley JF, Schlossman SF, Morimoto C. The 1A4 molecule (CD27) is involved in T cell activation. J Immunol. 1991;147(5):1477-83.

59. Oelke K, Lu Q, Richardson D, Wu A, Deng C, Hanash S, et al. Overexpression of CD70 and overstimulation of IgG synthesis by lupus T cells and T cells treated with DNA methylation inhibitors. Arthritis Rheum. 2004;50(6):1850-60. https://doi.org/10.1002/art.20255.

60. Zhao M, Sun Y, Gao F, Wu X, Tang J, Yin H, et al. Epigenetics and SLE: RFX1 downregulation causes CD11a and CD70 overexpression by altering epigenetic modifications in lupus CD4+ T cells. J Autoimmun. 2010;35(1):58-69. https://doi.org/10.1016/j.jaut.2010.02.002.

61. Zhao M, Wu X, Zhang Q, Luo S, Liang G, Su Y, et al. RFX1 regulates CD70 and CD11a expression in lupus T cells by recruiting the histone methyltransferase SUV39H1. Arthritis Res Ther. 2010;12(6):R227. https://doi. org/10.1186/ar3214.

62. Sunahori K, Nagpal K, Hedrich CM, Mizui M, Fitzgerald LM, Tsokos GC. The catalytic subunit of protein phosphatase 2A (PP2Ac) promotes DNA hypomethylation by suppressing the phosphorylated mitogen-activated protein kinase/extracellular signal-regulated kinase (ERK) kinase (MEK)/ phosphorylated ERK/DNMT1 protein pathway in T-cells from controls and systemic lupus erythematosus patients. J Biol Chem. 2013;288(30):21936-44. https://doi.org/10.1074/jbc.M113.467266.

63. Podack ER, Young JD, Cohn ZA. Isolation and biochemical and functional characterization of perforin 1 from cytolytic T-cell granules. Proc Natl Acad Sci U S A. 1985;82(24):8629-33. https://doi.org/10.1073/pnas.82.24.8629.

64. Hedrich CM, Rauen T, Apostolidis SA, Grammatikos AP, Rodriguez Rodriguez N, loannidis C, et al. Stat3 promotes IL-10 expression in lupus $\mathrm{T}$ cells through trans-activation and chromatin remodeling. Proc Natl Acad Sci U S A. 2014;111(37):13457-62. https://doi.org/10. 1073/pnas.1408023111.

65. Zhao M, Tang J, Gao F, Wu X, Liang Y, Yin H, et al. Hypomethylation of IL10 and IL13 promoters in CD4+ T cells of patients with systemic lupus enythematosus. Biomed Biotechnol. 2010;2010:931018. https://doi.org/10.1155/2010/931018.

66. Fang TJ, Lin YZ, Liu CC, Lin CH, Li RN, Wu CC, et al. Methylation and gene expression of histone deacetylases 6 in systemic lupus erythematosus. Int J Rheum Dis. 2016;19(10):968-73. https://doi.org/10.1111/1756-185X.12783.

67. Marks PA, Dokmanovic M. Histone deacetylase inhibitors: discovery and development as anticancer agents. Expert Opin Investig Drugs. 2005;14(12): 1497-511. https://doi.org/10.1517/13543784.14.12.1497.

68. Zhao S, Wang Y, Liang Y, Zhao M, Long H, Ding S, et al. MicroRNA-126 regulates DNA methylation in CD4+ T cells and contributes to systemic lupus erythematosus by targeting DNA methyltransferase 1. Arthritis Rheum. 2011;63(5):1376-86. https://doi.org/10.1002/art.30196.

69. Pan W, Zhu S, Yuan M, Cui H, Wang L, Luo X, et al. MicroRNA-21 and microRNA-148a contribute to DNA hypomethylation in lupus CD4+ T cells by directly and indirectly targeting DNA methyltransferase 1. J Immunol. 2010;184(12):6773-81. https://doi.org/10.4049/jimmunol.0904060.

70. Xin Q, Li J, Dang J, Bian X, Shan S, Yuan J, et al. miR-155 deficiency ameliorates autoimmune inflammation of systemic lupus erythematosus by targeting S1pr1 in Faslpr/lpr mice. J Immunol. 2015;194(11):5437-45. https://doi.org/10.4049/jimmunol.1403028.

71. Lu MM, Wang J, Pan HF, Chen GM, Li J, Cen H, et al. Increased serum RANTES in patients with systemic lupus erythematosus. Rheumatol Int 2012;32(5):1231-3. https://doi.org/10.1007/s00296-010-1761-2.

72. Smolen JS, Aletaha D, McInnes IB. Rheumatoid arthritis. Lancet. 2016; 388(10055):2023-38. https://doi.org/10.1016/S0140-6736(16)30173-8.

73. Joo YB, Park Y, Kim K, Bang SY, Bae SC, Lee HS. Association of CD8(+) T-cells with bone erosion in patients with rheumatoid arthritis. Int J Rheum Dis. 2018;21(2):440-6. https://doi.org/10.1111/1756-185X.13090.
74. Glossop JR, Emes RD, Nixon NB, Packham JC, Fryer AA, Mattey DL, et al. Genome-wide profiling in treatment-naive early rheumatoid arthritis reveals DNA methylome changes in T and B lymphocytes. Epigenomics. 2016;8(2):209-24. https://doi.org/10.2217/epi.15.103.

75. Richardson B, Scheinbart L, Strahler J, Gross L, Hanash S, Johnson M. Evidence for impaired T cell DNA methylation in systemic lupus erythematosus and rheumatoid arthritis. Arthritis Rheum. 1990;33(11):1665-73. https://doi.org/ 10.1002/art.1780331109.

76. Corvetta A, Della Bitta R, Luchetti MM, Pomponio G. 5-Methylcytosine content of DNA in blood, synovial mononuclear cells and synovial tissue from patients affected by autoimmune rheumatic diseases. J Chromatogr. 1991;566(2):481-91. https://doi.org/10.1016/0378-4347(91)80265-E.

77. Cribbs AP, Kennedy A, Penn H, Amjadi P, Green P, Read JE, et al. Methotrexate restores regulatory $T$ cell function through demethylation of the FoxP3 upstream enhancer in patients with rheumatoid arthritis. Arthritis Rheumatol. 2015;67(5):1182-92. https://doi.org/10.1002/art.39031.

78. de Andres MC, Perez-Pampin E, Calaza M, Santaclara FJ, Ortea I, GomezReino JJ, et al. Assessment of global DNA methylation in peripheral blood cell subpopulations of early rheumatoid arthritis before and after methotrexate. Arthritis Res Ther. 2015;17:233. https://doi.org/10.1186/s13075015-0748-5.

79. Nakano K, Whitaker JW, Boyle DL, Wang W, Firestein GS. DNA methylome signature in rheumatoid arthritis. Ann Rheum Dis. 2013;72(1):110-7. https:// doi.org/10.1136/annrheumdis-2012-201526.

80. de la Rica L, Urquiza JM, Gomez-Cabrero D, Islam AB, Lopez-Bigas N, Tegner $J$, et al. Identification of novel markers in rheumatoid arthritis through integrated analysis of DNA methylation and microRNA expression. J Autoimmun. 2013;41:6-16. https://doi.org/10.1016/j.jaut.2012.12.005.

81. Gillespie J, Savic S, Wong C, Hempshall A, Inman M, Emery P, et al. Histone deacetylases are dysregulated in rheumatoid arthritis and a novel histone deacetylase 3-selective inhibitor reduces interleukin-6 production by peripheral blood mononuclear cells from rheumatoid arthritis patients. Arthritis Rheum. 2012;64(2):418-22. https://doi.org/10.1002/art.33382.

82. Wendling D, Abbas W, Godfrin-Valnet M, Kumar A, Guillot X, Khan KA, et al. Dysregulated serum IL-23 and SIRT1 activity in peripheral blood mononuclear cells of patients with rheumatoid arthritis. PLoS One. 2015; 10(3):e0119981. https://doi.org/10.1371/journal.pone.0119981.

83. Kawabata T, Nishida K, Takasugi K, Ogawa H, Sada K, Kadota Y, et al. Increased activity and expression of histone deacetylase 1 in relation to tumor necrosis factor-alpha in synovial tissue of rheumatoid arthritis. Arthritis Res Ther. 2010;12(4):R133. https://doi.org/10.1186/ar3071.

84. Nishida K, Komiyama T, Miyazawa S, Shen ZN, Furumatsu T, Doi H, et al. Histone deacetylase inhibitor suppression of autoantibody-mediated arthritis in mice via regulation of p16INK4a and p21(WAF1/Cip1) expression. Arthritis Rheum. 2004;50(10):3365-76. https://doi.org/10.1002/art.20709.

85. Horiuchi M, Morinobu A, Chin T, Sakai Y, Kurosaka M, Kumagai S. Expression and function of histone deacetylases in rheumatoid arthritis synovial fibroblasts. J Rheumatol. 2009;36(8):1580-9. https://doi.org/10.3899/jirheum.081115.

86. Vojinovic J, Damjanov N, D'Urzo C, Furlan A, Susic G, Pasic S, et al. Safety and efficacy of an oral histone deacetylase inhibitor in systemic-onset juvenile idiopathic arthritis. Arthritis Rheum. 2011;63(5):1452-8. https://doi. org/10.1002/art.30238.

87. Huber LC, Brock M, Hemmatazad H, Giger OT, Moritz F, Trenkmann M, et al. Histone deacetylase/acetylase activity in total synovial tissue derived from rheumatoid arthritis and osteoarthritis patients. Arthritis Rheum. 2007;56(4):1087-93. https://doi.org/10.1002/art.22512.

88. Wada TT, Araki Y, Sato K, Aizaki Y, Yokota K, Kim YT, et al. Aberrant histone acetylation contributes to elevated interleukin-6 production in rheumatoid arthritis synovial fibroblasts. Biochem Biophys Res Commun. 2014;444(4): 682-6. https://doi.org/10.1016/j.bbrc.2014.01.195.

89. Ahmed S, Riegsecker S, Beamer M, Rahman A, Bellini JV, Bhansali P, et al. Largazole, a class I histone deacetylase inhibitor, enhances TNF-alphainduced ICAM-1 and VCAM-1 expression in rheumatoid arthritis synovial fibroblasts. Toxicol Appl Pharmacol. 2013;270(2):87-96. https://doi.org/10. 1016/j.taap.2013.04.014.

90. Li J, Wan Y, Guo Q, Zou L, Zhang J, Fang Y, et al. Altered microRNA expression profile with miR-146a upregulation in CD4+ T cells from patients with rheumatoid arthritis. Arthritis Res Ther. 2010;12(3):R81. https://doi.org/ 10.1186/ar3006.

91. Zhou Q, Haupt S, Kreuzer JT, Hammitzsch A, Proft F, Neumann C, et al. Decreased expression of miR-146a and miR-155 contributes to an abnormal 
Treg phenotype in patients with rheumatoid arthritis. Ann Rheum Dis. 2015; 74(6):1265-74. https://doi.org/10.1136/annrheumdis-2013-204377.

92. Yang G, Wu D, Zeng G, Jiang O, Yuan P, Huang S, et al. Correlation between miR-126 expression and DNA hypomethylation of CD4+ T cells in rheumatoid arthritis patients. Int J Clin Exp Pathol. 2015;8(8): 8929-36.

93. van der Geest KS, Smigielska-Czepiel K, Park JA, Abdulahad WH, Kim HW, Kroesen BJ, et al. SF Treg cells transcribing high levels of $\mathrm{BCl}-2$ and microRNA-21 demonstrate limited apoptosis in RA. Rheumatology (Oxford). 2015:54(5):950-8. https://doi.org/10.1093/rheumatology/keu407.

94. Hugle T, O'Reilly S, Simpson R, Kraaij MD, Bigley V, Collin M, et al. Tumor necrosis factor-costimulated T lymphocytes from patients with systemic sclerosis trigger collagen production in fibroblasts. Arthritis Rheum. 2013; 65(2):481-91. https://doi.org/10.1002/art.37738

95. Lei W, Luo Y, Lei W, Luo Y, Yan K, Zhao S, et al. Abnormal DNA methylation in CD4+ T cells from patients with systemic lupus erythematosus, systemic sclerosis, and dermatomyositis. Scand J Rheumatol. 2009;38(5):369-74. https://doi.org/10.1080/03009740902758875.

96. Lian X, Xiao R, Hu X, Kanekura T, Jiang H, Li Y, et al. DNA demethylation of CD40l in CD4+ T cells from women with systemic sclerosis: a possible explanation for female susceptibility. Arthritis Rheum. 2012;64(7):2338-45. https://doi.org/10.1002/art.34376.

97. Wang Y, Shu Y, Xiao Y, Wang Q, Kanekura T, Li Y, et al. Hypomethylation and overexpression of ITGAL (CD11a) in CD4(+) T cells in systemic sclerosis. Clin Epigenetics. 2014;6(1):25. https://doi.org/10.1186/1868-7083-6-25.

98. Jiang $H$, Xiao R, Lian X, Kanekura T, Luo Y, Yin Y, et al. Demethylation of TNFSF7 contributes to CD70 overexpression in CD4+ T cells from patients with systemic sclerosis. Clin Immunol. 2012;143(1):39-44. https://doi.org/10. 1016/j.clim.2012.01.005

99. Fukasawa C, Kawaguchi Y, Harigai M, Sugiura T, Takagi K, Kawamoto M, et al. Increased CD40 expression in skin fibroblasts from patients with systemic sclerosis (SSc): role of CD40-CD154 in the phenotype of SSC fibroblasts. Eur J Immunol. 2003;33(10):2792-800. https://doi.org/10.1002/eji.200324088.

100. Allanore Y, Borderie D, Meune C, Lemarechal H, Weber S, Ekindjian OG, et al. Increased plasma soluble CD40 ligand concentrations in systemic sclerosis and association with pulmonary arterial hypertension and digital ulcers. Ann Rheum Dis. 2005;64(3):481-3. https://doi.org/10.1136/ard.2003.020040.

101. Komura K, Fujimoto M, Yanaba K, Matsushita T, Matsushita Y, Horikawa M, et al. Blockade of CD40/CD40 ligand interactions attenuates skin fibrosis and autoimmunity in the tight-skin mouse. Ann Rheum Dis. 2008;67(6):867-72. https://doi.org/10.1136/ard.2007.073387.

102. Akhmetshina A, Palumbo $K$, Dees $C$, Bergmann $C$, Venalis $P$, Zerr $P$, et al. Activation of canonical Wnt signalling is required for TGF-beta-mediated fibrosis. Nat Commun. 2012;3:735. https://doi.org/10.1038/ncomms1734.

103. Dees C, Schlottmann I, Funke R, Distler A, Palumbo-Zerr K, Zerr P, et al. The Wht antagonists DKK1 and SFRP1 are downregulated by promoter hypermethylation in systemic sclerosis. Ann Rheum Dis. 2014;73(6):1232-9. https://doi.org/10.1136/annrheumdis-2012-203194.

104. Wang Y, Fan PS, Kahaleh B. Association between enhanced type I collagen expression and epigenetic repression of the FLI1 gene in scleroderma fibroblasts. Arthritis Rheum. 2006;54(7):2271-9. https://doi.org/10.1002/art.21948.

105. Xiao C, Rajewsky K. MicroRNA control in the immune system: basic principles. Cell. 2009;136(1):26-36. https://doi.org/10.1016/j.cell.2008.12.027.

106. Wang Q, Xiao Y, Shi Y, Luo Y, Li Y, Zhao M, et al. Overexpression of JMJD3 may contribute to demethylation of H3K27me3 in CD4+ T cells from patients with systemic sclerosis. Clin Immunol. 2015;161(2):396-9. https:// doi.org/10.1016/j.clim.2015.03.006.

107. Huber LC, Distler JH, Moritz F, Hemmatazad H, Hauser T, Michel BA, et al. Trichostatin a prevents the accumulation of extracellular matrix in a mouse model of bleomycin-induced skin fibrosis. Arthritis Rheum. 2007;56(8):2755-64. https://doi.org/10.1002/art.22759.

108. Hemmatazad H, Rodrigues HM, Maurer B, Brentano F, Pileckyte M, Distler JH, et al. Histone deacetylase 7, a potential target for the antifibrotic treatment of systemic sclerosis. Arthritis Rheum. 2009;60(5):1519-29. https://doi.org/10. 1002/art.24494.

109. Maurer B, Stanczyk J, Jungel A, Akhmetshina A, Trenkmann M, Brock M, et al. MicroRNA-29, a key regulator of collagen expression in systemic sclerosis. Arthritis Rheum. 2010;62(6):1733-43. https://doi.org/10.1002/art.27443.

110. Xiao J, Meng XM, Huang XR, Chung AC, Feng YL, Hui DS, et al. miR-29 inhibits bleomycin-induced pulmonary fibrosis in mice. Mol Ther. 2012;20(6):1251-60. https://doi.org/10.1038/mt.2012.36.
111. Sing T, Jinnin M, Yamane K, Honda N, Makino K, Kajihara I, et al. microRNA92a expression in the sera and dermal fibroblasts increases in patients with scleroderma. Rheumatology (Oxford). 2012;51(9):1550-6. https://doi.org/10. 1093/rheumatology/kes120.

112. Zhu H, Luo H, Li Y, Zhou Y, Jiang Y, Chai J, et al. MicroRNA-21 in scleroderma fibrosis and its function in TGF-beta-regulated fibrosis-related genes expression. J Clin Immunol. 2013;33(6):1100-9. https://doi.org/10. 1007/s10875-013-9896-z.

113. Pottier N, Maurin T, Chevalier B, Puissegur MP, Lebrigand K, Robbe-Sermesant $\mathrm{K}$, et al. Identification of keratinocyte growth factor as a target of microRNA155 in lung fibroblasts: implication in epithelial-mesenchymal interactions. PLoS One. 2009;4(8):e6718. https://doi.org/10.1371/journal.pone.0006718.

114. Honda N, Jinnin M, Kajihara I, Makino T, Makino K, Masuguchi S, et al. TGFbeta-mediated downregulation of microRNA-196a contributes to the constitutive upregulated type I collagen expression in scleroderma dermal fibroblasts. J Immunol. 2012;188(7):3323-31. https://doi.org/10.4049/ jimmunol.1100876.

115. Yin $\mathrm{H}$, Zhao M, Wu X, Gao F, Luo Y, Ma L, et al. Hypomethylation and overexpression of CD70 (TNFSF7) in CD4+ T cells of patients with primary Sjogren's syndrome. J Dermatol Sci. 2010;59(3):198-203. https://doi.org/10. 1016/j.jdermsci.2010.06.011

116. Yu X, Liang G, Yin H, Ngalamika O, Li F, Zhao M, et al. DNA hypermethylation leads to lower FOXP3 expression in CD4+ T cells of patients with primary Sjogren's syndrome. Clin Immunol. 2013;148(2):254-7. https://doi.org/10.1016/j.clim.2013.05.005.

117. Shen L, Suresh L, Wu J, Xuan J, Li H, Zhang C, et al. A role for lymphotoxin in primary Sjogren's disease. J Immunol. 2010;185(10):6355-63. https://doi. org/10.4049/jimmunol.1001520

118. Imgenberg-Kreuz J, Sandling JK, Almlof JC, Nordlund J, Signer L, Norheim $\mathrm{KB}$, et al. Genome-wide DNA methylation analysis in multiple tissues in primary Sjogren's syndrome reveals regulatory effects at interferon-induced genes. Ann Rheum Dis. 2016;75(11):2029-36. https://doi.org/10.1136/ annrheumdis-2015-208659.

119. Thabet Y, Le Dantec C, Ghedira I, Devauchelle V, Cornec D, Pers JO, et al. Epigenetic dysregulation in salivary glands from patients with primary Sjogren's syndrome may be ascribed to infiltrating B cells. J Autoimmun. 2013;41:175-81. https://doi.org/10.1016/j.jaut.2013.02.002.

120. Konsta OD, Le Dantec C, Charras A, Cornec D, Kapsogeorgou EK, Tzioufas $A G$, et al. Defective DNA methylation in salivary gland epithelial acini from patients with Sjogren's syndrome is associated with SSB gene expression, anti-SSB/LA detection, and lymphocyte infiltration. J Autoimmun. 2016;68: 30-8. https://doi.org/10.1016/j.jaut.2015.12.002.

121. Konsta OD, Charras A, Le Dantec C, Kapsogeorgeou E, Bordron A, Brooks WH, et al. Epigenetic modifications in salivary glands from patients with Sjogren's syndrome affect cytokeratin 19 expression. Bull Group Int Rech Sci Stomatol Odontol. 2016;53(1):e01

122. Pauley KM, Stewart CM, Gauna AE, Dupre LC, Kuklani R, Chan AL, et al. Altered miR-146a expression in Sjogren's syndrome and its functional role in innate immunity. Eur J Immunol. 2011;41(7):2029-39. https://doi.org/10. 1002/eji.201040757.

123. Huang W, Connor E, Rosa TD, Muir A, Schatz D, Silverstein J, et al. Although DR3-DQB1*0201 may be associated with multiple component diseases of the autoimmune polyglandular syndromes, the human leukocyte antigen DR4-DQB1*0302 haplotype is implicated only in beta-cell autoimmunity. J Clin Endocrinol Metab. 1996;81(7):2559-63. https://doi.org/10.1210/jcem.81. 7.8675578.

124. Mastrandrea LD. An overview of organ-specific autoimmune diseases including immunotherapy. Immunol Investig. 2015;44(8):803-16. https://doi. org/10.3109/08820139.2015.1099409.

125. Lesage $\mathrm{S}$, Goodnow CC. Organ-specific autoimmune disease: a deficiency of tolerogenic stimulation. J Exp Med. 2001;194(5):F31-6. https://doi.org/10. 1084/jem.194.5.F31.

126. Wang Yl, McDuffie M, Lafferty KJ. Antigen presentation and effector mechanisms in 'auto-immune' diabetes. J Gastroenterol Hepatol. 1991;6(6): 574-9. https://doi.org/10.1111/j.1440-1746.1991.tb00913.x.

127. Balazs C. Hashimoto's thyroiditis, the model of organ-specific autoimmune disorders. Orv Hetil. 2007;148(Suppl 1):31-3. https://doi.org/10.1556/OH.2007. 28032.

128. Greer JM, McCombe PA. The role of epigenetic mechanisms and processes in autoimmune disorders. Biologics. 2012;6:307-27. https://doi.org/10.2147/ BTT.S24067. 
129. Ciechomska M, O'Reilly S. Epigenetic modulation as a therapeutic Prospect for treatment of autoimmune rheumatic diseases. Mediat Inflamm. 2016;2016:9607946. https://doi.org/10.1155/2016/9607946.

130. Lee HJ, Li CW, Hammerstad SS, Stefan M, Tomer Y. Immunogenetics of autoimmune thyroid diseases: a comprehensive review. J Autoimmun. 2015; 64:82-90. https://doi.org/10.1016/j.jaut.2015.07.009.

131. McLachlan SM, Rapoport B. Breaking tolerance to thyroid antigens: changing concepts in thyroid autoimmunity. Endocr Rev. 2014;35(1):59-105. https://doi.org/10.1210/er.2013-1055.

132. Wang B, Shao X, Song R, Xu D, Zhang JA. The emerging role of epigenetics in autoimmune thyroid diseases. Front Immunol. 2017;8:396. https://doi.org/ 10.3389/fimmu.2017.00396.

133. Cai TT, Muhali FS, Song RH, Qin Q, Wang X, Shi LF, et al. Genome-wide DNA methylation analysis in graves' disease. Genomics. 2015;105(4):204-10. https://doi.org/10.1016/j.ygeno.2015.01.001.

134. Limbach M, Saare M, Tserel L, Kisand K, Eglit T, Sauer S, et al. Epigenetic profiling in CD4+ and CD8+ T cells from graves' disease patients reveals changes in genes associated with $T$ cell receptor signaling. J Autoimmun. 2016;67:46-56. https://doi.org/10.1016/j.jaut.2015.09.006.

135. Arakawa Y, Watanabe M, Inoue N, Sarumaru M, Hidaka Y, Iwatani Y. Association of polymorphisms in DNMT1, DNMT3A, DNMT3B, MTHFR and MTRR genes with global DNA methylation levels and prognosis of autoimmune thyroid disease. Clin Exp Immunol. 2012;170(2):194-201. https://doi.org/10.1111/j.1365-2249.2012.04646.x.

136. Kolarz B, Majdan M. Epigenetic aspects of rheumatoid arthritis: contribution of non-coding RNAs. Semin Arthritis Rheum. 2017;46(6):724-31. https://doi. org/10.1016/j.semarthrit.2017.01.003.

137. Sarumaru M, Watanabe M, Inoue N, Hisamoto Y, Morita E, Arakawa Y, et al Association between functional SIRT1 polymorphisms and the clinical characteristics of patients with autoimmune thyroid disease. Autoimmunity. 2016;49(5):329-37. https://doi.org/10.3109/08916934.2015.1134506.

138. Bernecker C, Lenz L, Ostapczuk MS, Schinner S, Willenberg H, Ehlers M, et al. MicroRNAs miR-146a1, miR-155_2, and miR-200a1 are regulated in autoimmune thyroid diseases. Thyroid. 2012;22(12):1294-5. https://doi.org/ 10.1089/thy.2012.0277

139. Peng H, Liu Y, Tian J, Ma J, Tang X, Yang J, et al. Decreased expression of microRNA-125a-3p upregulates interleukin-23 receptor in patients with Hashimoto's thyroiditis. Immunol Res. 2015;62(2):129-36. https://doi.org/10. 1007/s12026-015-8643-3.

140. Hashemi M, Bahari G, Naderi M, Sadeghi-Bojd S, Taheri M. Pri-miR-34b/c rs4938723 polymorphism is associated with the risk of childhood acute lymphoblastic leukemia. Cancer Genet. 2016;209(11):493-6. https://doi.org/ 10.1016/j.cancergen.2016.09.009.

141. Cai T, Li J, An X, Yan N, Li D, Jiang Y, et al. Polymorphisms in MIR499A and MIR125A gene are associated with autoimmune thyroid diseases. Mol Cell Endocrinol. 2017:440:106-15. https://doi.org/10.1016/j.mce.2016.11.017

142. Wang Y, Bi Y, Chen X, Li C, Li Y, Zhang Z, et al. Histone deacetylase SIRT1 negatively regulates the differentiation of Interleukin-9-producing CD4(+) T cells. Immunity. 2016:44(6):1337-49. https://doi.org/10.1016/j.immuni.2016. 05.009.

143. Zhang J, Lee SM, Shannon S, Gao B, Chen W, Chen A, et al. The type III histone deacetylase Sirt1 is essential for maintenance of T cell tolerance in mice. J Clin Invest. 2009;119(10):3048-58. https://doi.org/10.1172/JCI38902.

144. Yang H, Lee SM, Gao B, Zhang J, Fang D. Histone deacetylase sirtuin 1 deacetylates IRF1 protein and programs dendritic cells to control Th17 protein differentiation during autoimmune inflammation. J Biol Chem. 2013;288(52):37256-66. https://doi.org/10.1074/jbc.M113.527531.

145. Brooks WH, Renaudineau Y. Epigenetics and autoimmune diseases: the $X$ chromosome-nucleolus nexus. Front Genet. 2015;6:22. https://doi.org/10. 3389/fgene.2015.00022

146. Invernizzi P, Pasini S, Selmi C, Miozzo M, Podda M. Skewing of $X$ chromosome inactivation in autoimmunity. Autoimmunity. 2008;41(4):272-7. https://doi.org/10.1080/08916930802024574.

147. Brix TH, Knudsen GP, Kristiansen M, Kyvik KO, Orstavik KH, Hegedus L. High frequency of skewed $X$-chromosome inactivation in females with autoimmune thyroid disease: a possible explanation for the female predisposition to thyroid autoimmunity. J Clin Endocrinol Metab. 2005:90(11):5949-53. https://doi.org/10.1210/jc.2005-1366.

148. Ishido N, Inoue N, Watanabe M, Hidaka Y, Iwatani Y. The relationship between skewed $X$ chromosome inactivation and the prognosis of Graves and Hashimoto's diseases. Thyroid. 2015;25(2):256-61. https://doi.org/10. 1089/thy.2014.0318.

149. Fodor A, Cozma A, Karnieli E. TBC update: personalized epigenetic management of diabetes. Per Med. 2017;14(6):531-49. https://doi.org/10. 2217/pme-2017-0043.

150. Olsson AH, Volkov P, Bacos K, Dayeh T, Hall E, Nilsson EA, et al. Genomewide associations between genetic and epigenetic variation influence mRNA expression and insulin secretion in human pancreatic islets. PLoS Genet. 2014;10(11):e1004735. https://doi.org/10.1371/journal.pgen.1004735.

151. Rui J, Deng S, Lebastchi J, Clark PL, Usmani-Brown S, Herold KC. Methylation of insulin DNA in response to proinflammatory cytokines during the progression of autoimmune diabetes in NOD mice. Diabetologia. 2016;59(5): 1021-9. https://doi.org/10.1007/s00125-016-3897-4

152. Alejandro EU, Bozadjieva N, Blandino-Rosano M, Wasan MA, Elghazi L, Vadrevu S, et al. Overexpression of kinase-dead mTOR impairs glucose homeostasis by regulating insulin secretion and not beta-cell mass. Diabetes. 2017;66(8):2150-62. https://doi.org/10.2337/db16-1349.

153. Bacos K, Gillberg L, Volkov P, Olsson AH, Hansen T, Pedersen O, et al. Bloodbased biomarkers of age-associated epigenetic changes in human islets associate with insulin secretion and diabetes. Nat Commun. 2016;7:11089. https://doi.org/10.1038/ncomms11089.

154. Brasacchio D, Okabe J, Tikellis C, Balcerczyk A, George P, Baker EK, et al. Hyperglycemia induces a dynamic cooperativity of histone methylase and demethylase enzymes associated with gene-activating epigenetic marks that coexist on the lysine tail. Diabetes. 2009;58(5):1229-36. https:/doi.org/ $10.2337 / \mathrm{db08}-1666$.

155. Syreeni A, El-Osta A, Forsblom C, Sandholm N, Parkkonen M, Tarnow L, et al. Genetic examination of SETD7 and SUV39H1/H2 methyltransferases and the risk of diabetes complications in patients with type 1 diabetes. Diabetes. 2011;60(11):3073-80. https://doi.org/10.2337/db11-0073.

156. Li Y, Zhao M, Hou C, Liang G, Yang L, Tan Y, et al. Abnormal DNA methylation in CD4+ T cells from people with latent autoimmune diabetes in adults. Diabetes Res Clin Pract. 2011;94(2):242-8. https://doi.org/10.1016/j. diabres.2011.07.027.

157. Wang Z, Zheng Y, Hou C, Yang L, Li X, Lin J, et al. DNA methylation impairs TLR9 induced Foxp3 expression by attenuating IRF-7 binding activity in fulminant type 1 diabetes. J Autoimmun. 2013;41:50-9. https://doi.org/10. 1016/j.jaut.2013.01.009

158. Miao F, Smith DD, Zhang L, Min A, Feng W, Natarajan R. Lymphocytes from patients with type 1 diabetes display a distinct profile of chromatin histone H3 lysine 9 dimethylation: an epigenetic study in diabetes. Diabetes. 2008:57(12):3189-98. https://doi.org/10.2337/db08-0645.

159. Patel T, Patel V, Singh R, Jayaraman S. Chromatin remodeling resets the immune system to protect against autoimmune diabetes in mice. Immunol Cell Biol. 2011;89(5):640-9. https://doi.org/10.1038/icb.2010.144.

160. Hezova R, Slaby O, Faltejskova P, Mikulkova Z, Buresova I, Raja KR, et al. microRNA-342, microRNA-191 and microRNA-510 are differentially expressed in T regulatory cells of type 1 diabetic patients. Cell Immunol. 2010;260(2): 70-4. https://doi.org/10.1016/j.cellimm.2009.10.012.

161. Sippl W, Jung M, Mannhold R, Buschmann H, Holenz J. Epigenetic drug discovery: Wiley; 2019. https://www.wiley-vch.de/en/areas-interest/naturalsciences/epigenetic-drug-discovery-978-3-527-34314-0.

162. Farh KK, Marson A, Zhu J, Kleinewietfeld M, Housley WJ, Beik S, et al. Genetic and epigenetic fine mapping of causal autoimmune disease variants. Nature. 2015;518(7539):337-43. https://doi.org/10.1038/nature13835.

Ready to submit your research? Choose BMC and benefit from:

- fast, convenient online submission

- thorough peer review by experienced researchers in your field

- rapid publication on acceptance

- support for research data, including large and complex data types

- gold Open Access which fosters wider collaboration and increased citations

- maximum visibility for your research: over $100 \mathrm{M}$ website views per year

At $\mathrm{BMC}$, research is always in progress.

Learn more biomedcentral.com/submissions 